\title{
Polymorphism: an evaluation of the potential risk to the quality of drug products from the Farmácia Popular Rede Própria
}

\author{
Olímpia Maria Martins Santos ${ }^{1,2}$, Maria Esther Dias Reis ${ }^{2}$, Jennifer Tavares Jacon², Mônica Esselin \\ de Sousa Lino², Juliana Savioli Simões², Antonio Carlos Doriguetto ${ }^{1,2, *}$
}

\author{
${ }^{1}$ Institute of Chemistry, Federal University of Alfenas, Alfenas, MG, Brazil; ${ }^{2}$ Faculty of Pharmaceutical Sciences, Federal \\ University of Alfenas, Alfenas, MG, Brazil
}

\begin{abstract}
Polymorphism in solids is a common phenomenon in drugs, which can lead to compromised quality due to changes in their physicochemical properties, particularly solubility, and, therefore, reduce bioavailability. Herein, a bibliographic survey was performed based on key issues and studies related to polymorphism in active pharmaceutical ingredient (APIs) present in medications from the Farmácia Popular Rede Própria. Polymorphism must be controlled to prevent possible ineffective therapy and/or improper dosage. Few mandatory tests for the identification and control of polymorphism in medications are currently available, which can result in serious public health concerns.
\end{abstract}

Uniterms: Polymorphism. Medicines/quality control. Medicines/solubility. Medicines/bioavailability.

O polimorfismo em sólidos é um fenômeno frequente em fármacos e pode levar a problemas na qualidade dos medicamentos por alterar suas propriedades físico-químicas, em especial a solubilidade e, consequentemente, a biodisponibilidade. Nesse trabalho realizou-se levantamento bibliográfico sobre os principais estudos e problemas relacionados ao polimorfismo em fármacos presentes nos medicamentos disponibilizados pela Farmácia Popular do Brasil. O polimorfismo deve ser controlado a fim de evitar possível ineficácia terapêutica e/ou dosagem inapropriada dos medicamentos. Destacamos que são poucos os ensaios obrigatórios para identificação e controle desse fenômeno em medicamentos, o que pode acarretar grande problema de saúde pública.

Unitermos: Polimorfismo. Medicamentos/controle de qualidade. Medicamentos/solubilidade. Medicamentos/biodisponibilidade.

\section{INTRODUCTION}

The Brazilian Governmental Program Farmácia Popular Rede Própria was implemented to ensure access to low-cost medications that are considered essential for health for Brazilian citizens (Brasil, 2003). Some medications are manufactured and distributed through this nationwide chain. The Farmácia Popular Rede Própria is managed by Fundação Oswaldo Cruz (FIOCRUZ). The list of available medications is defined by the Ministry of Health based on epidemiological studies of the Brazilian population (Brasil, 2004). The drugs analyzed herein are all from the Farmácia Popular Rede Própria, which is

"Correspondence: A. C. Doriguetto. Instituto de Química, Universidade Federal de Alfenas. Rua Gabriel Monteiro da Silva, 700 - Centro - 37130-000 - Alfenas - MG, Brasil. E-mail: doriguetto@unifal-mg.edu.br hereafter referred to as FPRP.

Drug formulations provided by the FPRP are typically solid, which is consistent with the findings of a survey published in 2010 that revealed that over $80 \%$ of all medications are commercialized as tablets (Thayer, 2010). This predominance of solid drug formulations reflects the greater chemical stability of solid state compared with liquid state formulations (Nunn et al., 2005; Lee et al., 2011). Moreover, the development, manufacture, transportation, storage and supply of solid state formulations are simpler and less expensive in comparison to liquid state formulations (Nunn et al., 2005). However, solid state formulations also present challenges, such as polymorphism (Lee et al., 2011). This review focuses on the current knowledge of polymorphism in solid pharmaceuticals and the potential risk to the quality of drug products provided by the FPRP. 


\section{POLYMORPHISM}

\section{Definition and General Considerations}

Polymorphism occurs when a solid compound exists in two or more crystal forms. Polymorphs are compounds with an identical chemical composition in which the molecules are arranged in at least two different ways in the crystalline state (Bilton et al., 1999; Karpinski, 2006; Desiraju, 2008; Purohit et al., 2009). In pharmaceutical science, however, the term is used to designate several solid state forms of drugs and excipients, including amorphous forms, solvates, hydrates, salts and co-crystals (Aaltonen et al., 2009).

The amorphous form does not possess a defined order in its arrangement. Although the amorphous form is the most soluble form, it exhibits the lowest stability (Haisa et al., 1974; Lowes et al., 1987; Chieng et al., 2009).

In amorphous and crystalline forms, a solid drug may be anhydrous or a solvate/hydrate. When a solid form contains a solvent, it is known as a solvate. When the solvent is water, it is termed a hydrate (European Pharmapoeia, 2008).

Due to the frequent presence of water in the environment and its use in solvent blendings during the crystallization process, the formation of hydrated drugs is common. Because the water molecule is small and able to form hydrogen bonds, it is easily incorporated into the crystalline lattice of drugs both occupying spaces and stabilizing the structure (Gillon et al., 2003).

A survey performed in 1999 on drugs described in the European Pharmacopoeia revealed that one-third of the 808 products listed therein could form hydrates (Griesser, 2006). In Brazil, drugs commercialized as hydrates include the following: amoxicillin trihydrate, ampicillin trihydrate, cephalexin monohydrate, sodium dipyrone monohydrate, lidocaine hydrochloride monohydrate, meropenem trihydrate, methyldopa sesquihydrate, pantoprazole sesquihydrate, morphine sulfate pentahydrate, and dexamethasone acetate monohydrate (Farmacopeia Brasileira, 2010).

In addition to molecular crystals, drug anhydrates or solvates/hydrates, co-crystals, and salts also occur. Co-crystals are drug solids defined as multicomponent molecular crystals in which at least one of the compounds is an active pharmaceutical ingredient (API) (Bond, 2007; Schultheiss et al., 2009). Salts are considered different from co-crystals provided that they are crystals formed by ionic multicomponents (Mohamed et al., 2009). The FDA has recently published a Regulatory Classification of Pharmaceutical Co-Crystals (FDA, 2013) in which co-crystal is defined as "Crystalline materials composed of two or more molecules within the same crystal lattice" and polymorphs as "Different crystalline forms of the same drug substance. This may include solvation or hydration products (also known as pseudopolymorphs) and amorphous forms".

However, the definitions for these solid forms are matters of debate among the scientific community, regulatory agencies, and industrial groups, without a clear consensus (Schultheiss et al., 2009; Aitipamula et al., 2012).

Moreover, a nomenclature for polymorphs has not been established. Generally, different polymorphic forms of identical molecules are denoted by numerical (Carstensen, 2001) or alphabetical sequences; they can also be differentiated by means of hydration or solvation levels. In general, polymorphs are designated by the chronological order in which they have been reported (Carstensen, 2001).

The occurrence of polymorphism and its effects on solid products are attributed to existing intermolecular bonds. These noncovalent bonds, such as hydrogen bonds and van der Waals, $\pi-\pi$, and electrostatic interactions, determine the arrangement of the molecules in a crystal (Desiraju, 1995, 2001; Moulton et al., 2001; Purohit et al., 2009). API molecules are produced by atoms connected by covalent bonds, whereas crystals consist of molecules arranged through intermolecular interactions. The differences in these interactions can lead to distinct polymorphic forms and vice-versa (Blagden et al., 2007).

Any variation in the intermolecular arrangement of solid materials will alter the physical and chemical properties because these characteristics are intrinsically determined by its crystalline form, with the possibility of affecting bioavailability and stability (Byrn et al., 1999; ICH Q6A, 1999; Bauer et al., 2001; Erk et al., 2004; Lee et al., 2011).

According to Lee et al., 2011, the properties that vary as a consequence of the polymorphic form of the active pharmaceutical ingredient are the following: a) chemical: chemical reactivity and photochemical reactivity; b) kinetic: the rate of dissolution and stability; c) mechanical: compactability, hardness, powder flow, and friability; d) physical: conductivity, density, hygroscopicity, and particle morphology; e) surface: interfacial tension, surface area, and surface free energy; and f) thermodynamic: chemical potential, free energy, and solubility; enthalpy and entropy; heat capacity; melting and sublimation; and vapor pressure. 


\section{Challenges for the Pharmaceutical Industry}

One of the first reports concerning the influence of polymorphism on drugs dates back to 1967 (Aguiar et al., 1967). In this study, the bioavailability of chloramphenicol palmitate in suspension was evaluated in humans, and it was concluded that the distinct $\mathrm{A}$ and $\mathrm{B}$ polymorphic forms exhibited not only different dissolution rates but also differences in serum levels. Form A, which is more stable, did not exhibit adequate bioavailability, whereas form $\mathrm{B}$, which is metastable, exhibited greater bioavailability (Aguiar et al., 1967).

Although the effects of polymorphism on drugs have been known since the 1960s, it was only until the case of Norvir ${ }^{\circledR}$ (ritonavir), which is used for the control of acquired immunodeficiency syndrome (AIDS), that highlighted polymorphism as a serious concern for the pharmaceutical industry (Aaltonen et al., 2009). During the development of Norvir $^{\circledR}$, only a single polymorphic form was identified. In 1998, several lots of capsules did not pass the dissolution test due to the appearance of a new polymorphic form (denoted form II) that had formed during the manufacturing process, which was more stable and not very soluble (Chemburkar et al., 2000; Bauer et al., 2001). Thus, the medication was removed from the market due to the inability to manufacture the desired polymorphic form (form I) (Lee et al., 2011). To resolve this issue, Abbott Laboratories was required to spend hundreds of millions of dollars with an estimated loss of US\$250m in sales in 1998 alone (Goldbek et al., 2011).

The reformulation of Norvir ${ }^{\mathbb{B}}$ using the more stable form required approximately one year, in which patients were deprived of this important medication (Peterson et al., 2006). The impact on the standard of living of these patients caused by drug polymorphism highlights the serious consequences of drug polymorphism as a public health concern.

A similar situation occurred with rotigotine. Originally licensed as a polymorphism-free API, Schwarz Pharma commercialized rotigotine in 2006 as a transdermal medication to treat the signs and symptoms of Parkinson's disease (Goldbek et al., 2011). Nevertheless, in 2008, rotigotine $\left(\right.$ Neupro $\left.^{\circledR}\right)$ was removed from the market due to the transformation into a less soluble polymorphic substance that had crystallized and was not absorbed by the skin (Goldbek et al., 2011; FDA, 2008).

Due to its strategic importance for public health, medications available in the 'FPRP' program (Brasil, 2012) were selected for this study to perform a bibliographic survey on the occurrence of polymorphism, its possible influence on the physicochemical properties of the API and, consequently, on the final quality of the pharmaceutical formulations.

\section{Bioequivalence and Bioavailability}

To reach an expected therapeutic aim, it is imperative that pharmaceuticals exist at the expected concentration. Considering solid formulations, the medications must release the appropriate amount of API at a suitable rate for the desired therapeutic effect and be bioequivalent to the reference product. Moreover, these formulations must exhibit physicochemical stability within their shelf life (Aulton, 2005).

The Biopharmaceutical Classification System (BCS) may provide useful information to develop strategies to control polymorphism because the solubility, dissolution, and permeability of an API are determinants of its bioavailability. According to the BCS, drugs are subdivided into the following four categories: I, high solubility and high permeability; II, low solubility and high permeability; III, high solubility and low permeability; and IV, low solubility and low permeability. A drug is considered to have high solubility when its highest recommended dose is soluble in $250 \mathrm{~mL}$ of aqueous medium in a $\mathrm{pH}$ range of 1-7.5 (Amidon et al., 1995).

Considering that polymorphic forms of an API can exhibit different solubility levels, choosing the incorrect polymorphic form or the occurrence of a phase transition during the manufacture and storage may affect the bioavailability and, consequently, the efficacy and safety, particularly for drugs for which dissolution is the absorption-limiting factor (classes II and IV) (FDA, 2007; Llinàs et al.,2008).

When the occurrence of two or more solid forms of an API, including polymorphs, is identified during the development of a drug, the chosen form is typically the most stable (Shingal et al., 2004; Von Raumer, Dannappel, Hilfiker, 2012). In addition to being easily controllable, the more stable polymorphic form also complies with requirements described in the Q6A Guide of the International Commission on Harmonization (ICH) for solid form selection (Grant et al., 2004).

\section{KNOWN CRYSTAL FORMS OF APIS PROVI- DED BY THE FPRP}

Table I summarizes the different APIs distributed by the FPRP as solid pharmaceutical formulations, for which the therapeutic class and relevant information on polymorphism are also included. Despite 79 of 113 $(69.9 \%)$ solid formulations from the FPRP, the number 
TABLE I - Solid-state forms of Farmácia Popular drugs

\begin{tabular}{|c|c|c|c|c|c|}
\hline API & Indication & BCS & $\#$ & Stable form* & Reference \\
\hline Acyclovir & Antiviral & III & 6 & I & $\begin{array}{l}\text { (TSRL inc, 2012; Kristl et al., 1996; Sohn et } \\
\text { al., 2008; Lutker et al., 2011; Tutughamiarso et } \\
\text { al, 2012) }\end{array}$ \\
\hline Acetylsalicylic Acid & Analgesic & IV & 2 & I & $\begin{array}{l}\text { (TSRL inc, 2012; Klein et al., 1994; } \\
\text { Vishweshwar } \text { et al., 2005; Bond et al., 2011) }\end{array}$ \\
\hline Ibuprofen & Analgesic & II & 2 & I & $\begin{array}{l}\text { (TSRL inc, 2012; Shankland et al., 1996; Erk } \\
\text { et al., 2004; Stone et al., 2009; Derollez et al., } \\
\text { 2010) }\end{array}$ \\
\hline Acetaminophen & Analgesic & IV & 6 & I & $\begin{array}{l}\text { (TSRL inc, 2012; Haisa et al., 1974; Naumov } \\
\text { et al., 1998; McGregor et al., 2002; Parkin et } \\
\text { al., 2002; Peterson et al., 2002; Fabbiani } \text { et al., } \\
\text { 2004) }\end{array}$ \\
\hline Albendazole & Anthelmintic & II & 2 & II & (TSRL inc, 2012; Pranzo et al., 2010) \\
\hline Mebendazole & Anthelmintic & II & 3 & A & $\begin{array}{l}\text { (TSRL inc, 2012; Rodriguez-Caabeiro et al., } \\
\text { 1987; Martins et al., 2009; Ferreira et al., 2010) }\end{array}$ \\
\hline Loratadine & Antiallergic & II & 2 & + & (TSRL inc, 2012; Khunt, 2008; Gala, 1999) \\
\hline$\underline{\text { Ferrous sulfate }}$ & Antianemic & $\dagger$ & 3 & + & (Wehner et al., 1976) \\
\hline Folic acid & Antianemic & IV & 1 & Dihydrate & (TSRL inc, 2012; Mastropaolo et al., 1980) \\
\hline Diazepam & Antianxiety & II & 2 & $\$$ & (TSRL inc, 2012; Camerman et al.,1972) \\
\hline $\begin{array}{l}\text { Amiodarone } \\
\text { hydrochloride }\end{array}$ & Antiarrhythmic & II & 1 & $\ddagger$ & (Wu et al., 2005; Cody et al., 1989) \\
\hline Digoxin & Antiarrhythmic & I & 3 & Amorphous & $\begin{array}{l}\text { (TSRL inc, 2012; Chiou et al., 1979; Go et al., } \\
\text { 1980; Eberhard et al., 1983) }\end{array}$ \\
\hline $\begin{array}{l}\text { Verapamil } \\
\text { hydrochloride }\end{array}$ & $\begin{array}{l}\text { Antiarrhythmic, } \\
\text { Antihypertensive }\end{array}$ & II & 1 & + & $\begin{array}{l}\text { (TSRL inc, 2012; Carpy et al., 1985; Yoshida et } \\
\text { al., 2010) }\end{array}$ \\
\hline Amoxicillin & Antibiotic & IV & 1 & Trihydrate & (TSRL inc, 2012; Boles et al., 1978) \\
\hline Azithromycin & Antibiotic & II or IV & 3 & Dihydrate & $\begin{array}{l}\text { (TSRL inc, 2012; Blanco M et al., 2005; } \\
\text { Montejo-Bernardo et al., 2009) }\end{array}$ \\
\hline Benzylpenicillin & Antibiotic & I or III & 1 & $\mathrm{I}$ & (TSRL inc, 2012; Dexter et al., 1978) \\
\hline $\begin{array}{l}\text { Cephalexin } \\
\text { (hydrochloride or } \\
\text { sodium salt) } \\
\end{array}$ & Antibiotic & II & 8 & $\begin{array}{c}\text { IV } \\
\text { (monohydrate) }\end{array}$ & $\begin{array}{l}\text { (Otsuka et al., 1983; Stephenson et al., 1998; } \\
\text { Kennedy et al., 2003; Kasim et al., 2004; } \\
\text { Aguiar } \text { et al., 2011) }\end{array}$ \\
\hline Ciprofloxacin & Antibiotic & III & 3 & II (hydrate) & $\begin{array}{l}\text { (TSRL inc, 2012; Turel et al., 2003; Fabbiani } \\
\text { et al., 2008; Fabbiani et al., 2009; Fabbiani } \text { et } \\
\text { al., 2011) }\end{array}$ \\
\hline Doxycycline & Antibiotic & IV & 2 & $\$$ & (TSRL inc, 2012; Legendre et al., 2012) \\
\hline Erythromycin & Antibiotic & IV & 4 & Dihydrate & $\begin{array}{l}\text { (TSRL inc, 2012; Fukumori et al., 1983; } \\
\text { Stephenson et al., 1997; Miroshnyk et al., } \\
\text { 2006) }\end{array}$ \\
\hline Sulfamethoxazole & Antibiotic & IV & 4 & $\begin{array}{c}\text { III } \\
\text { (hemihydrate) }\end{array}$ & $\begin{array}{l}\text { (TSRL inc, 2012; Maury et al., 1985; Hartauer } \\
\text { et al., 1992; Takasuka et al.,2001; Price } \text { et al., } \\
\text { 2005; Fioritto } \text { et al., 2007) }\end{array}$ \\
\hline Sulfasalazine & Antibiotic & II & 2 & + & $\begin{array}{l}\text { (TSRL inc, 2012; Bilton et al., 1999; Filip et } \\
\text { al., 2001) }\end{array}$ \\
\hline Trimethoprim & Antibiotic & IV & 1 & 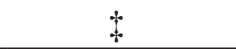 & (TSRL inc, 2012; Koetzle et al., 1976) \\
\hline
\end{tabular}


TABLE I - Solid-state forms of Farmácia Popular drugs (cont.)

\begin{tabular}{|c|c|c|c|c|c|}
\hline API & Indication & BCS & $\#$ & Stable form* & Reference \\
\hline Carbamazepine & Anticonvulsant & II & 6 & Dihydrate & $\begin{array}{l}\text { (TSRL inc, 2012; Himes et al., 1981; Rebou } \\
\text { et al., 1981; Lowes et al., 1987; Lisgarten et } \\
\text { al., 1989; Lang et al., 2002; Grzesiak et al., } \\
\text { 2003; Harris et al., 2005; Gelbrich et al., 2006; } \\
\text { Kogan et al., 2008; Arlin et al., 2011) }\end{array}$ \\
\hline Phenytoin & Anticonvulsant & II & 1 & $\mathrm{I}$ & (TSRL inc, 2012; Nokhodchi et al., 2003) \\
\hline Phenobarbital & Anticonvulsant & IV & 13 & A & $\begin{array}{l}\text { (TSRL inc, 2012; Otsuka et al., 1993; Platteau } \\
\text { et al., 2005; Zencirci et al., 2009; Zencirci } \text { et } \\
\text { al., 2010) }\end{array}$ \\
\hline $\begin{array}{l}\text { Amitriptyline } \\
\text { hydrochloride }\end{array}$ & Antidepressant & I & 1 & I & (TSRL inc, 2012; Klein et al., 1994) \\
\hline $\begin{array}{l}\text { Fluoxetine } \\
\text { hydrochloride }\end{array}$ & Antidepressant & I & 1 & I & (TSRL inc, 2012; Robertson et al., 1988) \\
\hline Glibenclamide & Antidiabetic & II & 1 & $\mathrm{I}$ & (TSRL inc, 2012; Byrn et al., 1986) \\
\hline $\begin{array}{l}\text { Metformin } \\
\text { hydrochloride }\end{array}$ & Antidiabetic & III & 2 & A & (TSRL inc, 2012; Childs et al., 2004) \\
\hline $\begin{array}{l}\text { Metoclopramide } \\
\text { hydrochloride }\end{array}$ & Antiemetic & II or IV & 3 & $\ddagger$ & (TSRL inc, 2012; Pabón et al., 1996) \\
\hline Clonazepam & Antiepileptic & $\dagger$ & 1 & $\mathrm{I}$ & (Chananont et al., 1979) \\
\hline Ketoconazole & Antifungal & II & 2 & $\begin{array}{c}\text { I (enantiomer } \\
+ \text { ) }\end{array}$ & $\begin{array}{l}\text { (Peeters et al., 1979; Peeters et al., 2004; Wu e } \\
\text { al., 2005) }\end{array}$ \\
\hline Fluconazole & Antifungal & III & 4 & I & $\begin{array}{l}\text { (TSRL inc, 2012; Alkhamis et al., 2002; Caira } \\
\text { et al., 2004; Chandavarkar, Jindai, Kulkarni, } \\
\text { 2011) }\end{array}$ \\
\hline Miconazole Nitrate & Antifungal & $\dagger$ & 3 & $\$$ & (Pedersen et al., 1993; Peeters et al., 2004) \\
\hline $\begin{array}{l}\text { Promethazine } \\
\text { hydrochloride }\end{array}$ & Antihistamine & I & 2 & 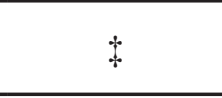 & (TSRL inc, 2012; Borodi et al., 2012) \\
\hline Atenolol & Antihypertensive & III & 2 & I & $\begin{array}{l}\text { (TSRL inc, 2012; Esteves De Castro et al., } \\
\text { 2007) }\end{array}$ \\
\hline Captopril & Antihypertensive & III & 2 & $\mathrm{I}(\mathrm{B})$ & $\begin{array}{l}\text { (TSRL inc, 2012; Haoming et al., 1985; } \\
\text { Fekete, 1997; Zhenhong et al., 2011) }\end{array}$ \\
\hline Enalapril maleate & Antihypertensive & I & 2 & II & $\begin{array}{l}\text { (TSRL inc, 2012; Précigoux et al., 1986; } \\
\text { Evjolfsson, 2003; Kiang et al., 2003) }\end{array}$ \\
\hline Losartan & Antihypertensive & III & 5 & I & $\begin{array}{l}\text { (TSRL inc, 2012; Campbell et al., 1997; } \\
\text { Dolitzky et al., 2004; Wu et al., 1993; } \\
\text { Fernández et al., 2002; Tessler et al., 2004) }\end{array}$ \\
\hline Methyldopa & Antihypertensive & III & 1 & + & (TSRL inc, 2012; Neuman et al., 1984) \\
\hline Nifedipine & Antihypertensive & II & 3 & $\mathrm{~A}=\mathrm{I}=\alpha$ & $\begin{array}{l}\text { (TSRL inc, 2012; Uekama et al., 1992; Grooff } \\
\text { et al., 1997; Gunn et al., 2012) }\end{array}$ \\
\hline $\begin{array}{l}\text { Propranolol } \\
\text { hydrochloride }\end{array}$ & Antihypertensive & I & 3 & II & $\begin{array}{l}\text { (TSRL inc, 2012; Bartolomei et al., 1999; } \\
\text { Bredikhin et al., 2004) }\end{array}$ \\
\hline Simvastatin & Antilipemic & II & 3 & I & $\begin{array}{l}\text { (TSRL inc, 2012; Cejka et al., 2003; Husak et } \\
\text { al., 2010) }\end{array}$ \\
\hline Biperiden & Antiparkinsonian & I & 1 & $\mathrm{I}$ & (TSRL inc, 2012; Codding, 1986) \\
\hline Carbidopa & Antiparkinsonian & $\mathrm{I}$ & $\ddagger$ & $t$ & (Lindenberg et al., 2004) \\
\hline
\end{tabular}


TABLE I - Solid-state forms of Farmácia Popular drugs (cont.)

\begin{tabular}{|c|c|c|c|c|c|}
\hline$\overline{\mathrm{API}}$ & Indication & BCS & $\#$ & Stable form* & Reference \\
\hline Levodopa & Antiparkinsonian & I & 2 & I & $\begin{array}{l}\text { (TSRL inc, 2012; Mostad et al., 1970; Mostad } \\
\text { et al., 1971; Howard et al., 1995) }\end{array}$ \\
\hline $\begin{array}{l}\text { Benserazide } \\
\text { hydrochloride }\end{array}$ & Antiparkinsonian & $\dagger$ & $t$ & $\$$ & $\ddagger$ \\
\hline Metronidazole & Antiprotozoal & IV & 1 & $t$ & (TSRL inc, 2012; Galván-Tejada et al., 2002) \\
\hline Chlorpromazine & Antipsychotic & II & 2 & Anhydrous & $\begin{array}{l}\text { (TSRL inc, 2012; McDowel, 1969; Klein et al., } \\
\text { 1986) }\end{array}$ \\
\hline Haloperidol & Antipsychotic & II & 1 & $\mathrm{I}$ & (TSRL inc, 2012; Prasanna et al., 2001) \\
\hline Omeprazole & Antiulcer & $\dagger$ & 1 & $\$$ & (Ohishi et al., 1989) \\
\hline $\begin{array}{l}\text { Ranitidine } \\
\text { hydrochloride }\end{array}$ & Antiulcer & III & 4 & II & $\begin{array}{l}\text { (TSRL inc, 2012; Ngooi et al., 1994, } \\
\text { Agatonovic-Kustrin et al., 1999; Hempel et al., } \\
\text { 2000; Chieng et al., 2006) }\end{array}$ \\
\hline $\begin{array}{l}\text { Oseltamivir } \\
\text { phosphate }\end{array}$ & Antiviral & I or III & 1 & $\$$ & (TSRL inc, 2012; Kang et al., 2012) \\
\hline Salbutamol sulfate & Bronchodilator & I & 3 & I & $\begin{array}{l}\text { (Lindenberg et al., 2004; Lulla et al., 2011, Rao } \\
\text { et al., 2011; Palacio et al., 2007) }\end{array}$ \\
\hline Allopurinol & $\begin{array}{c}\text { Chronic gout } \\
\text { treatment }\end{array}$ & IV & 1 & I & (TSRL inc, 2012; Prusiner et al., 1972) \\
\hline Ethinyl estradiol & Contraceptive & $\mathrm{I}$ & 1 & Hemihydrate & (TSRL inc, 2012; Guguta et al., 2008) \\
\hline Levonorgestrel & Contraceptive & $\mathrm{I}$ & 2 & + & (TSRL inc, 2012; Chang, Chen, 2009) \\
\hline Norethisterone & Contraceptive & I & 1 & $\$$ & $\begin{array}{l}\text { (Lindenberg et al., 2004; Reisch et al., 1993; } \\
\text { Shikii et al., 2005) }\end{array}$ \\
\hline Furosemide & Diuretic & IV & 3 & $\mathrm{I}$ & (TSRL inc, 2012; Babu et al., 2010) \\
\hline Hydrochlorothiazide & Diuretic & IV & 2 & + & (TSRL inc, 2012; Leech et al., 2008) \\
\hline Prednisone & Glucocorticoid & $\mathrm{I}$ & 1 & + & (Vogt et al., 2007; Suitchmezian et al., 2008) \\
\hline Azathioprine & Immunosuppressant & IV & 2 & $\$$ & $\begin{array}{l}\text { (TSRL inc, 2012; Cook, Bugg, 1975; } \\
\text { Acharya, 1984) }\end{array}$ \\
\hline Alendronate sodium & $\begin{array}{l}\text { Inhibitor of bone } \\
\text { resorption }\end{array}$ & III & 13 & $\ddagger$ & $\begin{array}{l}\text { (TSRL inc, 2012; Kieczykowski et al.,1990; } \\
\text { Vega et al., 1996; Finkelstein et al., 2004; } \\
\text { Asnani et al., 2009) }\end{array}$ \\
\hline $\begin{array}{l}\text { Isosorbide } \\
\text { mononitrate }\end{array}$ & Vasodilator & I & 2 & $\ddagger$ & (Fotaki, Vertzoni, 2010; Kanters et al., 1993) \\
\hline
\end{tabular}

\#: minimum number of known crystal structures; *: Room temperature; $\uparrow:$ Unclassified; and $\ddagger$ : Not reported.

Note: For the overall polymorphic forms, neither salts and solvates without pharmaceutical application nor co-crystals were considered.

of different solid APIs is 65 . This difference is due to the availability of more than one dosage for an identical API. Table I also includes the BCS class, known crystal structures and correct polymorph reported in the literature that is present in the medication for each API.

The Cambridge Structural Database (CSD, 2011) and Inorganic Crystal Structure Database (ICSD, 2002) was used to analyze crystalline structures by entering the compound name, molecular form, and chemical structure. Information on patents and indexed journals in the electronic databases SciFinder ${ }^{\odot}$ (2012) and Web of Science ${ }^{\odot}$ (2012) were also collected. Compound structures were included as single component forms, hydrates, salts, and solvates with pharmaceutical application. Biopharmaceutical classification was obtained at the Therapeutic System Research Laboratories, which is managed by Amidon et al., 2012 (TSRL inc 2012). Furthermore, a search was performed using the aforementioned electronic databases by combining the terms "name of the compound in English" and 
"polymorph" in the free search of databases. Articles that discussed solid state chemical polymorphism were included; articles that discussed other types of polymorphism were excluded.

Table I indicates that phenobarbital and alendronate sodium are the APIs with the most reported polymorphic crystal structures (11 forms each) followed by cephalexin ( 8 forms) and acetaminophen/carbamazepine/acyclovir ( 6 forms each). A total of 168 crystal structures were found for the 65 APIs listed in Table I, which resulted in a mean value of 2.67 polymorphs per API. Figure 1a illustrates that $42(65 \%)$ of the 65 APIs exhibit two or more polymorphs of known crystal structure. Only 21 (32\%) APIs do not exhibit more than one reported crystal form. However, it is important to emphasize that in this review, only polymorphs deposited in the $\mathrm{CSD}^{\odot}$ and $\mathrm{ICSD}^{\circ}$ or in articles indexed in SciFinder ${ }^{\odot}$ and Web of Science ${ }^{\circ}$ were considered. The revision work also indicates that no crystal structure is known for $2(3 \%)$ APIs listed in Table 1. For some APIs, the thermodynamically stable form (or preconized polymorphic form) is reported in the literature. This result is also summarized in Table I and is illustrated in Figure 1b. Noteworthy is the number of APIs $(24,37 \%)$ without studies indicating the correct crystal form, of which 13 (54\%) have two or more known polymorphic crystal structures.

Figures $1 \mathrm{c}$ and $1 \mathrm{~d}$ show the BCS classification of the 65 solid APIs available at the FPRP, illustrating that 31 (48\%) possess low solubility (classes II and IV). Figure 2
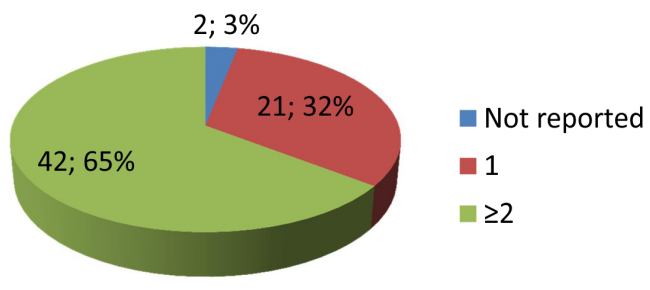

(a)

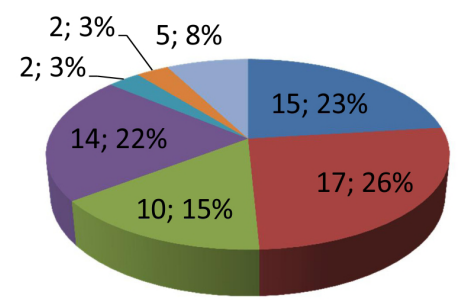

(c) shows the number of APIs with "unknown", "only one", and "two or more" crystal structures per BCS class. For $21(68 \%)$ of the 31 class II and IV APIs (low solubility), two or more crystal structures have been reported. For 17 (68\%) of the 25 class I and III APIs (high solubility), two or more polymorphic structures have been reported.

Despite 41 (63\%) APIs (Table 1) with more than one reported crystal structure, as previously mentioned, there are studies concerning the influence of polymorphism on drug performance for only $22(14.3 \%)$. Problems related to either the efficacy or the manufacture caused by polymorphism have been reported, i.e., for mebendazole, carbamazepine, estradiol, and acetaminophen.

\section{Albendazole and Mebendazole}

The antiparasitic albendazole and mebendazole are among the low solubility drugs with reported polymorphism. Albendazole is commercialized in form I (metastable), which is the most soluble form. Both forms I and II are stable under storage conditions; however, much care is required to control the form because of the possibility of undesirable polymorphic phase conversion in this API (Pranzo et al., 2010).

Mebendazole exhibits polymorphic forms A, B, and C, which differ in their biopharmaceutical and physicochemical properties. Polymorph $\mathrm{C}$ is the pharmaceutically preferred form due to its adequate aqueous solubility (Rodriguez et al., 1987; Charoenlarp et al., 1993). Form A is the most

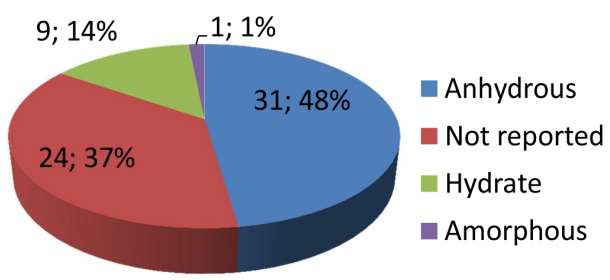

(b)

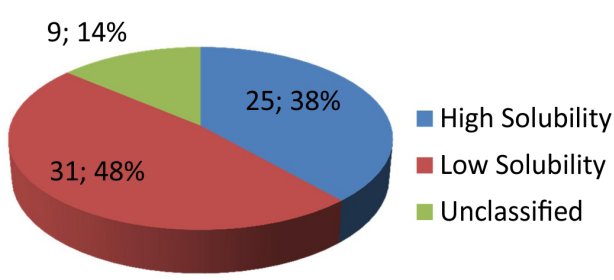

(d)

FIGURE 1. Statistical features of the 65 APIs available as solid formulations at the FPRP. (a) The number of different crystal structures (polymorphs when there are more than one structure); (b) the types of solid forms expected to be present in the solid formulation; (c) the distribution in the BCS (I = high permeability, high solubility; II = high permeability, low solubility; III = low permeability, high solubility; and IV = low permeability, low solubility); and (d) the distribution in the BCS indicating the APIs with high solubility (classes I and III) and low solubility (classes II and IV). 


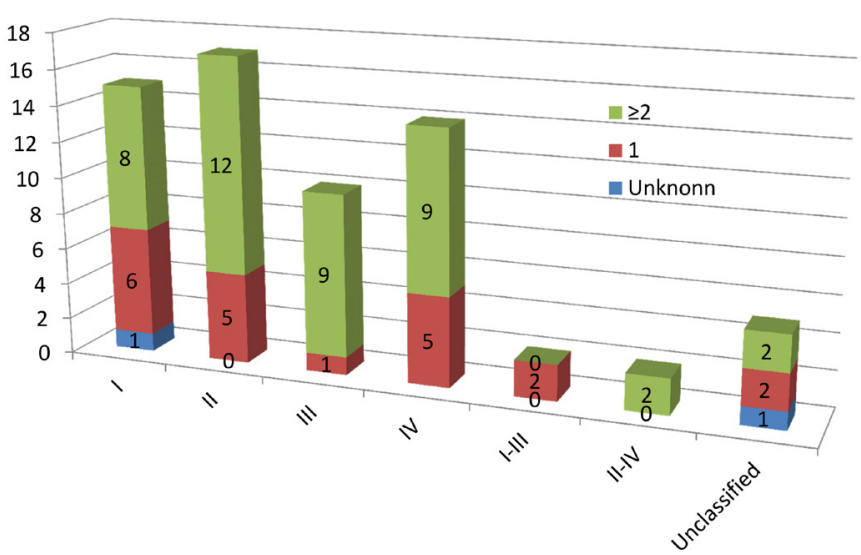

FIGURE 2. The number of different crystal structures distributed in the four classes of the BCS for the 65 APIs that are available as a solid formulation at the FPRP.

stable, less soluble form that is considered therapeutically ineffective (Rodriguez et al., 1987). In a clinical study with 958 children, the efficacy of polymorph A did not differ from the placebo (Charoenlarp et al., 1993). Costa et al. (1991) have shown that polymorph B is more soluble than polymorph C. Therefore, polymorph B should be avoided or a strategy to ensure the proper dosage must be developed to enable the drug to exert the desired effect. Form C, thus, recommended for oral use, is metastable and, in solution, may crystallize as the more stable form A (Rodriguez et al., 1987; Agatonovic-Kustrin et al., 2008). Moreover, regarding stability, the presence of small quantities of form $\mathrm{A}$ in tablets results in a rapid increase of transformation into other polymorphic forms. Four analyzed trademark drugs presented traces of form $\mathrm{A}$, and, in most of them, the shelf life was reduced to less than a month. These products also failed to comply with the acceptance criteria of the United States Pharmacopoeia (USP) and the Food and Drug Administration (FDA) in dissolution assays (Brits et al., 2010). Therefore, the anthelmintic efficacy of mebendazole is highly dependent on the polymorphism (Martins et al., 2009).

Quality control routine tests that may distinguish among polymorphic forms include the dissolution assay, IR spectroscopy, thermogravimetric analyses, and primarily powder X-ray diffraction measurements (Liebenberg et al., 1998). Nevertheless, it was observed that the mebendazole dissolution assay described in USP 25 did not distinguish among the three polymorphic forms. The recommended dissolution medium was $0.1 \mathrm{M}$ hydrochloride acid containing sodium lauryl sulfate (SLS). The solubility difference among the polymorphs had been masked with the inclusion of the surfactant, and the removal of SLS from the dissolution medium resolved the polymorphic forms (Swanepoel et al., 2003).

Despite this example, the USP 34 (2011) continues to recommend a dissolution medium that contains SLS. Therefore, much attention should be directed at quality control methods that are able to discriminate between polymorphic forms and that the polymorphic form present in the medication is the recommended form. In this respect, characterization using powder X-ray diffraction is very useful.

In 2005, an analysis of the raw materials and drug products containing mebendazole in the Brazilian market revealed the following alarming results: the expected form $\mathrm{C}$ was not found in any analyzed raw material, USP reference standard included. From the 10 analyzed medications, five contained polymorph $\mathrm{A}$, three contained polymorph $\mathrm{C}$, and two contained a mixture of polymorphs $\mathrm{B}$ and $\mathrm{C}$, with $\mathrm{B}$ as the majority. At the time the study was published, the mebendazole reference brand (manufactured by Abbott Laboratories) was altered. Polymorph $\mathrm{C}$ was not detected in this new reference medication, which also contained different polymorphs in different lots (Froehlich et al., 2005).

\section{Furosemide}

Another low solubility drug that exhibits problems related to the dissolution assay in official compendia is the diuretic furosemide. When the solubilities of furosemide polymorphs are compared, the metastable form II is found to be the most soluble (Matsuda et al., 1990). This API has been observed to undergo photolytic degradation from which the metastable forms suffer more than the thermodynamically stable form I (Matsuda et al., 1990; Villiers et al.1992). To differentiate furosemide polymorphic forms in pharmaceutical formulations, several dissolution mediums were tested, which resulted in a recommended medium at $\mathrm{pH} 2.2$ due to its ability to differentiate the commercialized form (form I) from the other forms (II and III) (Maggio et al., 2009).

Considering the diuretic furosemide as an example, the in vitro dissolution assay is an excellent tool to differentiate polymorphic forms and identify polymorphic phase transitions. Provided the test anticipates bioavailability and physical stability, it can evaluate the quality of a medication (Yu et al., 2003; Raw et al., 2004).

Therefore, methods that are described in official compendia must be carefully considered because, as observed with mebendazole, the recommended dissolution test for furosemide does not discriminate among forms (United States Pharmacopeia, 2011). Thus, 
the development of methods that are able to differentiate polymorphic forms is essential for the quality control of medications, particularly for low solubility drugs (Bonfilio et al., 2012).

\section{Fluconazole}

Fluconazole confirms the high frequency of hydrate occurrence in APIs. Fluconazole exists as a mixture of forms I and II and fluconazole monohydrate (Park et al., 2007). The solubility order among the polymorphs of this API is II (metastable) > I > monohydrate (Park et al., 2010), and forms I and II convert into the monohydrate when dissolved in water (Park et al., 2010). Polymorph II has been found to absorb humidity and form the monohydrate phase from both the environment and the excipient during either the storage phase or the manufacturing phase (Chandavarkar, Jindai, Kulkarni, 2011).

\section{Acyclovir}

The acyclovir in pharmaceutical formulations is present as a hydrate (polymorph V) (Kristl et al., 1996; Lutker et al., 2011). Unexpectedly, the hydrated form of acyclovir solubilizes more rapidly than the anhydrous form (Kristl et al., 1996; Stephenson et al., 1997), which is explained by the high thermodynamic stability and low hygroscopicity of the anhydrous form (Kristl et al., 1996).

\section{Cephalexin, Erythromycin, Ciprofloxacin, Sulfamethoxazole, and Digoxin}

A tendency to form hydrates is also observed in the antibiotics cephalexin, erythromycin, ciprofloxacin, and sulfamethoxazole. In pharmaceutical preparations, monohydrated cephalexin is the predominant polymorphic form (Aguiar et al., 2011). Cephalexin is also found in the dihydrated form, which, at room temperature, rapidly loses one molecule of water to form the monohydrated cephalexin (Kennedy et al., 2003). A similar phenomenon occurs with erythromycin, which is commercialized in its more stable and less soluble dihydrated form. This API loses its water molecules at relatively low temperature $\left(71^{\circ} \mathrm{C}\right)$ (Fukumor et al., 1983).

As for ciprofloxacin, the exposure of form I (anhydrous) to a relative humidity higher than $90 \%$ leads to the appearance of form II (hydrate), which is observed when an aqueous suspension of form I is prepared (Mafra et al., 2012).

For sulfamethoxazole, form II converts to the hemihydrate (form III) more rapidly than form I. In the solubility assay, a phase transition was not observed for form II, whereas form I converted to the hemihydrate under identical conditions (Fioritto et al., 2007).

Micronization with supercritical antisolvent has led to an increase in the sulfamethoxazole dissolution rate and has caused the phase transition of polymorph I to II, with a solubility ratio of 1.2 (Pudipeddi et al., 2005; Chang et al., 2008).

Studies revealed that for digoxin, the grinding process leads to amorphization (Florence et al., 1976). Storage of the amorphous form at room temperature results in a reduction in solubility (Chiou et al., 1979), which is a great concern considering that this antiarrhythmic has a narrow therapeutic window. Thermal stress of digoxin also results in polymorphic phase transitions (Eberhard et al., 1983).

\section{Carbamazepine}

The impact of polymorphism has been extensively studied on the anticonvulsant carbamazepine, highlighting its impact on product quality. In 1988, a clinical failure was reported for Tegretol ${ }^{\circledR}$ tablets (carbamazepine), likely due to the polymorphic phase transition from the anhydrous to the dihydrate form (Lee et al., 2011). Moreover, there are several reports of variability in the dissolution profile of commercially available carbamazepine tablets (Davidson, 1994; Meyer et al., 1992, 1998; Al-Zein et al., 1999; Lake et al., 1999; Mittapalli et al., 2008).

Carbamazepine is one of the few APIs for which the recommended polymorphic form is described in official compendia. Although such compendia determine form III for medical preparations, they do not define limits for the other forms (European Pharmacopeia, 2008; British Pharmacopeia, 2009; United States Pharmacopeia, 2011), and the manufacture of this API does not always result in pure crystalline phases (Rustichelli et al., 2000; Lang et al., 2002; Grzesiak et al., 2003; Quist et al., 2008; Javadzadeh et al., 2009; Diao et al., 2012; Wang et al., 2012), which emphasizes the need to develop methods to quantify the contamination of form III with other polymorphic forms (Kipouros et al., 2005).

A mixture of polymorphic forms has been observed in commercial samples of carbamazepine raw material (Šehić et al., 2010; Flicker et al., 2011). As expected, these polymorphs exhibit different dissolution rates. Form III converts to carbamazepine dihydrate (a less soluble form) more rapidly than form I, which critically affects the solubility and bioavailability of pharmaceutical preparations (Kobayashi et al., 2000).

When pure form III samples are compared, the effect of particle size on the dissolution rate is counterintuitive, 
i.e., a larger amount of small-sized particles results in a slower carbamazepine dissolution rate, which occurs because the narrow shape of these particles enables the conversion to the dehydrate (Flicker et al., 2011). Micronization of carbamazepine by expansion in supercritical solution appears to increase the solubility of the drug, although this process may lead to a phase transition (Bolten et al., 2012).

\section{Phenobarbital}

Six of the polymorphic forms of another anticonvulsant, phenobarbital (A, B, C (monohydrate), D (dioxane solvate), $\mathrm{E}$ (hemihydrate) and $\mathrm{F}$ ), were evaluated. The order of the dissolution rate among the forms is $\mathrm{F}>\mathrm{B}$ $>\mathrm{E}>\mathrm{C}>\mathrm{A}>\mathrm{D}$, and the order of the hardness among the tablets containing them is $\mathrm{D}>\mathrm{A}>\mathrm{C}>\mathrm{E}>\mathrm{B}=\mathrm{F}$ (Otsuka et al., 1994).

Under isothermal conditions $\left(45^{\circ} \mathrm{C}\right)$, phenobarbital stability was as follows: A, B, and F forms were stable at 0 and $75 \%$ relative humidity, whereas $C, D$, and $E$ forms underwent transformation during storage, with the transformation rate of form $\mathrm{D}$ as the fastest (Otsuka et al., 1993).

\section{Acetylsalicylic Acid}

The possibility of the occurrence of polymorphism in acetylsalicylic acid (ASA) antiinflammatory and analgesic products has been investigated since the 1960s (Tawashi, 1968). It was only in 2005 that polymorphism was verified in this API, in which it was found that form II (metastable) coexists with form I (Vishweshwar et al., 2005). Subsequently, form II was isolated, and its conversion into form I occurs at room temperature, which is accelerated by mechanical grinding (Varughese et al., 2011).

\section{Acetaminophen}

Acetaminophen, which is another analgesic and antithermic drug, is an example of manufacturing problems associated with polymorphism (Snider et al., 2004). Form II (metastable), in contrast to form I (stable), can be used in the manufacture of tablets, which is advantageous because the process is simpler and less expensive (Di et al., 1996; Nichols et al., 1998). To manufacture medications containing form I, commercially available agglutinant excipients are required, which increases the cost (Di et al., 1997; Nichols et al., 1998). Because the dissolution rate is similar for both form II and commercialized form I tablets, a possible transformation does not lead to problems with bioavailability (Di et al., 1996).

\section{Verapamil Hydrochloride, Enalapril, Losartan, and Propranolol}

For antihypertensive drugs that contain verapamil hydrochloride, studies were performed at temperatures varying from $25^{\circ} \mathrm{C}$ to $750{ }^{\circ} \mathrm{C}$ using several analytical techniques, and it was found that this API did not exhibit polymorphic forms at the evaluated conditions (Yoshida et al., 2010).

In the studies on enalapril, form II was observed to be much less stable than form I in tablets containing an identical amount of sodium hydrogen carbonate (Eyjolfsson, 2002). The increased ratio of sodium hydrogen carbonate in the tablet containing form II and the presence of desiccant in the blister packaging significantly decreased its degradation (Eyjolfsson, 2003).

Losartan antihypertensive form I is thermodynamically more stable and less soluble than form II at room temperature, and form II may convert to form I during storage (Wu et al., 1993; Crocker et al., 1997).

Both forms I and II of another antihypertensive, propranolol, are stable at room temperature even after grinding and compression. Polymorph I (metastable) is $34 \%$ more soluble than form II (commercially available) (Bartolomei et al., 1999).

\section{Ranitidine, Glibenclamide, and Estradiol}

Ranitidine, which is prescribed for the treatment of ulcers, exhibits polymorphic forms I and II with similar solubility and bioavailability (Bawazir et al., 1998; Parkin et al., 2002). Notwithstanding, a slight difference in stability was observed between these forms, and phase transitions can occur via water absorption, mechanical strength (Carstensen et al., 1995; Foster et al., 1998; Chieng et al., 2006) and during storage (Madan et al., 1994).

Glibenclamide form $\mathrm{I}$ is the most stable with a melting point of $175.4{ }^{\circ} \mathrm{C}$ and that of form II of $151.0^{\circ} \mathrm{C}$. Every form (I, II, III, and IV) was found to be stable below zero or $100 \%$ relative humidity, with form III as the most soluble (Sohn et al., 1997).

A polymorphism effect was also found for estradiol. Transdermal adhesives, which contain this drug, formed crystals during storage. The crystals belonged to different estradiol polymorphs and also to the polymeric adhesive (Variankaval et al., 1999). 


\section{QUALITY CONTROL OF POLYMORPHIC SOLID FORMS}

Single crystal and powder X-ray diffraction techniques are the most suitable and more utilized tools to study and characterize polymorphs in pharmaceutical solids because they provide unequivocal proof of either polymorphism existence or polymorphism occurrence (FDA, 2007). Powder X-ray diffraction is feasible for application in the quality control of polymorphism in capsules, tablets, and pastes, among others. For this purpose, the API must be crystalline and be present at a concentration greater than $5 \%(\mathrm{w} / \mathrm{w})$ in the formulation, which is the commonly adopted detection limit for phase quantification using PXRD techniques. The pharmaceutical formulation can be analyzed after minimal or no pretreatment of the sample without a requirement to separate the API from the excipients because most excipients are not detected by X-rays. Moreover, it is possible to simultaneously identify more than one API in the formulation (Phadnis et al., 1997).

Others important techniques such as microscopy, thermal analysis (e.g., differential scanning calorimetry, thermal gravimetric analysis, and hot-stage microscopy), and spectroscopy (e.g., infrared [IR], Raman, and solidstate nuclear magnetic resonance [ssNMR]) are also commonly used in the quality control of polymorphism in drugs. Diffraction, spectroscopic, and thermal techniques are considered complementary in the study of polymorphs. Polymorphic transitions can also be detected using drug product dissolution testing (FDA, 2007) because the test is demonstrably able to differentiate different forms.

Despite the vast accumulated scientific knowledge on the effects of phase transitions in APIs in the solid state, crystalline form characterization assays are not included in most monographs described in official compendia. Conversely, the FDA published the Guidance for Industry of FDA - ANDAs: Pharmaceutical Solid Polymorphism Chemistry, Manufacturing, and Controls Information that provides recommendations for the monitor and control of polymorphs in drug substances and/or drug products (FDA, 2007). However, in USP 35-NT 30, assays on powder X-ray diffraction are described in only 15 monographs from the 4,500 monographs that include APIs, excipients and drug products (United States Pharmacopeia, 2012).

\section{CONCLUSION}

For many drugs present in medications that are available at the FPRP, according to the best of the authors' knowledge, there are few studies that correlate polymorphism to possible influences on drug solubility as well as its clinical impact. Therefore, the existence of polymorphs may potentially be an important source of variation in pharmaceutical properties, which can cause problems concerning the stability, solubility and, consequently, efficacy and bioavailability of drug products. Relatively simple quality control tests allow the differentiation of polymorphs. However, the identification of the polymorphic phase is not a mandatory test for the large majority of drugs. Thus, more commitment is necessary by regulatory and quality control authorities to monitor polymorphism not only for FPRP medications but also for all commercial drugs. This monitoring includes the control of polymorphism in raw materials, manufacturing steps and finished products by the end of the shelf life of the drug. In this manner, possible public health concerns linked to polymorphism in medicines can be avoided.

\section{ACKNOWLEDGEMENTS}

We thank FAPEMIG (APQ-02685-09, APQ-0109310, APQ-02600-12, and PPM-00524-12), FINEP (Refs. 134/08 and 0336/09), CAPES (PNPD-2007 and PNPD2011) and $\mathrm{CNPq}(472623 / 2011-7$ and 476870/2011-9) for their financial support of this study. We also thank CNPq, CAPES, and FAPEMIG for research fellowships (ACD, MEDR, MESL and JSS). We thank the CSIC of Spain for the license to use the CSD.

\section{REFERENCES}

AALTONEN, J.; ALLESØ, M.; MIRZA, S.; KORADIA, V.; GORDON, K.C.; RANTANEN, J. Solid form screening - a review. Eur. J. Pharm. Biopharm., v.71, n.1, p.23-37, 2009.

ACHARYA, K.R. Crystal structure of 6-((1-methyl-4nitroimidazol-5-yl)thio) purine. P. Indian AS-Chem. Sci., v.93, n.2, p.183-187, 1984.

AGATONOVIC-KUSTRIN, S.; GLASS, B.D.; MANGAN, N.; SMITHSON, J. Analysing the crystal purity of mebendazole raw material and its stability in a suspension formulation. Int. J. Pharm., v.361, n.1-2, p.245-50, 2008.

AGATONOVIC-KUSTRIN, S.; WU, V.; RADES, T.; SAVILLE, D.; TUCKER, I.G. Powder diffractometric assay of two polymorphic forms of ranitidine hydrochloride. Int. J. Pharm., v.184, n.1, p.107-114, 1999. 
AGUIAR, D.L.M.; SAN GIL, R.A.S.; BORRE, L.B.; MARQUES, M.R.C.; GEMAL, A.L. Evaluation of polymorphs in cephalexin medicines by $13 \mathrm{C}$ solid state NMR. Int. J. Pharm. Pharm. Sci., v.3, n.3, p.293-298, 2011.

AGUIAR, J.A.; KRC JR, J.; KINKEL, A.W.; SAMYN, J.C. Effect of polymorphism on the absorption of chloramphenicol from chloramphenicol palmitate. $J$. Pharm. Sci., v.56, n.7, p.847-853, 1967.

AITIPAMULA, S.; BANERJEE, R.; BANSAL, A.K.; BIRADHA, K.; CHENEY, M.L.; CHOUDHURY, A.R.; DESIRAJU, G.R.; DIKUNDWAR, A.G.; DUBEY, R.; DUGGIRALA, N.; GHOGALE, P.P.; GHOSH, S.; GOSWAMI, P.K.; GOUD, N.R.; JETTI, R.K.R.; KARPINSKI, P.; KAUSHIK, P.; KUMAR, D.; KUMAR, V.; MOULTON, B.; MUKHERJEE, A.; MUKHERJEE, G.; MYERSON, A.S.; PURI, V.; RAMANAN, A.; RAJAMANNAR, T.; REDDY, C.M.; RODRIGUEZHORNEDO, N.; ROGERS, R.D.; ROW, T.N.G.; SANPHUI, P.; SHAN, N. SHETE, G.; SINGH, A.; SUN, C.C.; SWIFT, J.A.; THAIMATTAM, R.; THAKUR, T.S.; THAPER, R.K.; THOMAS, S.P.; TOTHADI, S.; VANGALA, V.R.; VARIANKAVAL, N.; VISHWESHWAR, P.; WEYNA, D.R.; ZAWOROTKO, M.J. Polymorphs, salts, and cocrystals: what's in a name? Cryst. Growth Des., v.12, n.5, p.2147-52, 2012.

ALKHAMIS, K.A.; OBAIDAT, A.A.; NUSEIRAT, A.F. Solidstate characterization of fluconazole. Pharm. Dev. Technol., v.7, n.4, p.491-503, 2002.

AL-ZEIN, H.; RIAD, L.E.; ABD-ELBARY, A. Effect of packaging and storage on the stability of carbamazepine tablets. Drug Dev. Ind. Pharm., v.25, n.2, p.223-227, 1999.

AMIDON, G.L.; LENNERNÄS, H.; SHAH, V.P.; CRISON, J.R. A theoretical basis for a biopharmaceutic drug classification: the correlation of in vitro drug product dissolution and in vivo bioavailability. Pharm. Res., v.12, n.3, p.413-420, 1995.

ARLIN, J-B.; PRICE, L.S.; PRICE, S.L.; FLORENCE, A.J. A strategy for producing predicted polymorphs: catemeric carbamazepine form V. Chem. Commun., v.47, n.25, p.7074$7076,2011$.
A S NAN I, M.; VYA S, K.; B HAT TA C H A R Y, A.; DEVARAKONDA, S.; CHAKRABORTY, S.; MUKHERJEE, A.K. Ab initio structure determination of anhydrous sodium alendronate from laboratory powder x-ray diffraction data. J. Pharm. Sci., v.98, n.6, p.21132121, 2009.

AULTON, M.E. Delineamento de formas farmacêuticas. 2.ed. Rio de Janeiro: Artmed. 2005. 678 p.

BABU, N.J.; CHERUKUVADA, S.; THAKURIA, R.; NANGIA, A. Conformational and synthon polymorphism in furosemide (Lasix). Cryst. Growth Des., v.10, n.4, p.19791989, 2010.

BARTOLOMEI, M.; BERTOCCHI, P.; RAMUSINO, M.C.; SANTUCCI, N.; VALVO, L. Physico-chemical characterizations of the modifications I and II of $(\mathrm{R}, \mathrm{S})$ propranolol hydrochloride: solubility and dissolution studies. J. Pharm. Biomed., v.21, n.2, p.299-309, 1999.

BAUER, J.; SPANTON, S.; HENRY, R.; QUICK, J.; DZIKI, W.; PORTER, W.; MORRIS, J. Ritonavir: an extraordinary example of conformational polymorphism. Pharm. Res., v.18, n.6, p.859-866, 2001.

BAWAZIR, S.A.; GOUDA, M.W.; EL-SAYED, Y.M.; ALKHAMIS, K.I.; AL-YAMANI, M.J.; NIAZY, E.M.; ALRASHOOD, K.A. Comparative bioavailability of two tablet formulations of ranitidine hydrochloride in healthy volunteers. Int. J. Clin. Pharmacol. Ther, v.36, n.54, p.270274, 1998.

BELSKY, A.; HELLENBRANDT, M.; KAREN, V.L.; LUKSCH, P. New developments in the Inorganic Crystal Structure Database (ICSD): accessibility in support of materials research and design. Acta Crystallogr. B., v.58, n.1, p.364-369, 2002.

BERNSTEIN, J. Polymorphism in molecular crystals. 3.ed. New York: Oxford University. 2002. 428 p.

BILTON, C.; HOWARD, J.A.K.; MADHAVI, N.N.L.; NANGIA, A.; DESIRAJU, G.R.; ALLEN, F.H.; CHICK, C.W. When is a polymorph not a polymorph? Helical trimeric O-H O synthons in trans-1,4-diethynylcyclohexane1,4-diol. Chem. Commun., v.17, p.1675-1676, 1999. 
BLAGDEN, N.; DE MATAS, M.; GAVAN, P.T.; YORK, P. Crystal engineering of active pharmaceutical ingredients to improve solubility and dissolution rates. Adv. Drug Delivery Rev., v.59, n.7, p.617-630, 2007.

BLAKE, A.J.; LIN, X.; SCHRÖEDER, M.; WILSON, C.; YUAN, R.X. The imide tautomer of sulfasalazine. Acta Crystallogr., Sect. C: Cryst. Struct. Commun., v.60, pt.4, p.O226-O228, 2004.

BLANCO, M.; VALDÉS, D.; LLORENTE, I.; BAYOD, M. Application of NIR spectroscopy in polymorphic analysis: study of pseudo-polymorphs stability. J. Pharm. Sci., v.94, n.6, p.1336-1342, 2005.

BOLES, M.O.; GIRVEN, R.J.; GANE, P.A.C. The structure of amoxycillin trihydrate and a comparison with the structures of ampicillin. Acta Crystallogr., Sect. B: Struct. Crystallogr. Cryst. Chem., v.B34, n.2, p.461-466, 1978.

BOLTEN, D.; TÜRK, M. Micronisation of carbamazepine through rapid expansion of supercritical solution (RESS). J. Supercrit. Fluids, v.62, p.32-40, 2012.

BOND, A.D. What is a co-crystal? Cryst. Eng. Comm., v.9, n.9, p.833-834, 2007.

BOND, A.D.; SOLANKO, K.A.; PARSONS, S.; REDDER, S.; BOESE, R. Single crystals of aspirin form II: crystallisation and stability. Cryst. Eng. Comm., v.13, n.2, p.399-401, 2011.

BONFILIO, R.; PIRES, S.A.; FERREIRA, L.M.B.; ALMEIDA, A.E.; DORIGUETTO, A.C.; ARAÚJO, M.B.; HÉRIDA, R.N.S. A discriminating dissolution method for glimepiride polymorphs. J. Pharm. Sci., v.101, n.2, p.794-804, 2012.

BORODI, G.; POP, M.M.; ONIJA, O.; FILIP, X. Distinct disordered forms of promethazine hydrochloride: a case of intergrowth of polymorphic domains? Cryst. Growth Des., v.12, n.12, p.5846-5851, 2012.

BRASIL. Presidência da Republica. Casa Civil. Subchefia para Assuntos Jurídicos. Medida Provisória n.154, 23 de dezembro de 2003. Autoriza a Fundação Oswaldo Cruz - Fiocruz a disponibilizar medicamentos, mediante ressarcimento, e dá outras providências. Available at: http:// www.planalto.gov.br/ccivil_03/MPV/Antigas_2003/154. htm. Acessed on: May 2012.
BRASIL. Decreto n.5.090, de 20 de maio de 2004. Regulamenta a Lei n.10.858, de 13 de abril de 2004, e institui o programa "Farmácia popular do Brasil", e dá outras providências. Diário Oficial da União, Brasília, n.97, 21 maio 2004. Seção 1, p.6.

BRASIL. Lei n.10.858, de 13 de abril de 2004. Autoriza a Fundação Oswaldo Cruz - Fiocruz a disponibilizar medicamentos, mediante ressarcimento, e dá outras providências. Diário Oficial da União, Brasília, n.71, apr. 14, 2004. Seção 1, p.1.

BREDIKHIN, A.A.; BREDIKHINA, Z.A.; GUBAIDULLIN, A.T.; KRIVOLAPOV, D.B.; LITVINOV, I.A. Rational approach to a conglomerate-forming propranolol derivative: pointed modifications of the crystal structure. Mendeleev Commun., v.14, n.6, p.268-270, 2004.

BRITISH Pharmacopoeia. 6.ed. London: Stationery Office, 2009. v.4, p.A146.

BRITS, M.; LIEBENBERG, W.; DE VILLIERS, M.M. Characterization of polymorph transformations that decrease the stability of tablets containing the WHO essential drug mebendazole. J. Pharm. Sci., v.99, n.3, p.1138-1151, 2010.

BYRN, S.R.; MCKENZIE, A.T.; HASSAN, M.M.; AL-BADR, A.A. Conformation of glyburide in the solid state and in solution. J. Pharm. Sci., v.75, n.6, p.596-600, 1986.

BYRN, S.R.; PFEIFFER, R.R.; STOWELL, J.G. Solid-state chemistry of drugs. 2.ed. West Lafayette: SSCI, 1999. 574 p.

CAIRA, M.R.; ALKHAMIS, K.A.; OBAIDAT, R.M. Preparation and crystal characterization of a polymorph, a monohydrate, and an ethyl acetate solvate of the antifungal fluconazole. J. Pharm. Sci., v.93, n.3, p.601-611, 2004.

CAMERMAN, A.; CAMERMAN, N. Stereochemical basis of anticonvulsant drug action. II. Molecular structure of diazepam. J. Am. Chem. Soc., v.94, n.1, p.268-272, 1972.

CAMPBELL JR., G.C.; DWIVEDI, A.M.; LEVORSE, D.A.; MCCAULEY, J.A.; RAGHAVAN, K.S. Polymorphs of losartan and the process for the preparation of form II of losartan. US Pat. 005608075A, 4 Mar. 1997. 24p. 
CARPY, A.; LÉGER, J.M.; MELCHIORRE, C. Structure of $\alpha$-isopropyl- $\alpha-((N$-methyl- $N$-homoveratryl $)-\gamma$ -aminopropyl)-3,4-dimethoxyphenylacetonitrile hydrochloride, verapamil, $\mathrm{C}_{27} \mathrm{H}_{38} \mathrm{~N}_{2} \mathrm{O}_{4} \cdot \mathrm{HCl}$. Acta Crystallogr., Sect.C: Cryst. Struct. Commun., v.41, n.4, p.624-627, 1985.

CARSTENSEN, J.T. One-component systems. In: Advanced pharmaceutical solids. New York: Marcel Dekker, 2001.p.1-11. (Drugs and the pharmaceutical sciences; v.110).

CARSTENSEN, J.T.; FRANCHINI, M.K. Isoenergic polymorphs. Drug Dev. Ind. Pharm., v.21, n.5, p.523-536, 1995.

CEJKA, J.; KRATOCHVÍL, B.; CÍSAROVÁ, I.; JEGOROV, A. Simvastatin. Acta Crystallogr., Sect. C: Cryst. Struct. Commun., v.59, n.8, p.O428-O430, 2003.

CHANANONT, P.; HAMOR, T.A.; MARTIN, I.L. 5-(2-Chlorophenyl)-1,3-Dihydro-7-Nitro-2H-1,4Benzodiazepin-2-One(Clonazepam), C15H10CLN3O3. Cryst. Struct. Commun., v.8, n.2, p.393-400, 1979.

CHANDAVARKAR, N.M.; JINDAI, K.C.; KULKARNI, S.S. Stabilized fluconazole polymorph III formulation. WO 2011/101862, Aug. 24, 2011. 26 p.

CHANG, Y.P.; TANG, M.; CHEN, Y.P. Micronization of sulfamethoxazole using the supercritical anti-solvent process. J. Mater. Sci., v.43, n.7, p.2328-2335, 2008.

CHANG, Y.S.; CHEN, S.P. Levonorgestrel crystallization. US Pat 2009/0069584, Mar. 12, 2009. 8 p.

CHAROENLARP, P.; WAIKAGUL, J.; MUENNOO, C.; SRINOPHAKUN, S.; KITAYAPORN, D. Efficacy of single-dose mebendazole, polymorphic forms $\mathrm{A}$ and $\mathrm{C}$, in the treatment of hookworm and Thichuris infections. Southeast Asian J. Trop. Med. Public Health, v.24, n.4, p.712-716, 1993.

CHEMBURKAR, S.R.; BAUER, J.; DEMING, K.; SPIWEK, H.; PATEL, K.; MORRIS, J.; HENRY, R.; SPANTON, S.; DZIKI, W.; PORTER, W.; QUICK, J.; BAUER, P.; DONAUBAUER, J.; NARAYANAN, B.A.; SOLDANI, M.; RILEY, D.; MCFARLAND, K. Dealing with the impact of ritonavir polymorphs on the late stages of bulk drug process development. Org. Process Res. Dev., v.4, n.5, p.413-417, 2000.
CHIENG, N.; AALTONEN, J.; SAVILLE, D.; RADES, T. Physical characterization and stability of amorphous indomethacin and ranitidine hydrochloride binary systems prepared by mechanical activation. Eur. J. Pharm. Biopharm., v.71, n.1, p.47-54, 2009.

CHIENG, N.; ZUJOVIC, Z.; BOWMAKER, G.; RADES, T.; SAVILLE, D. Effect of milling conditions on the solidstate conversion of ranitidine hydrochloride form 1. Int. J. Pharm., v.327, n.1/2, p.36-44, 2006.

CHILDS, S.L.; CHYALL, L.J.; DUNLAP, J.T.; COATES, D.A.; STAHLY, B.C.; STAHLY, G.P. A metastable polymorph of metformin hydrochloride: isolation and characterization using capillary crystallization and thermal microscopy techniques. Cryst. Growth Des., v.4, n.3, p.441-449, 2004.

CHIOU, W.L.; KYLE, L.E. Differential thermal, solubility, and ageing studies on various sources of digoxin and digitoxin powder: biopharmaceutical implications. J. Pharm. Sci., v.68, n.10, p.1224-1229, 1979.

CODDING, P.W. The structure and absolute configuration of $(+)$-biperiden: a chiral ligand for the pirenzepine biding site. Acta Crystallogr., Sect. B: Struct. Sci., v.B42, n.6, p.632-638, 1986.

CODY, V.; LUFT, J. Structure-activity relationships of antiarrhythmic agents: crystal structure of amiodarone hydrochloride and two derivatives, and their conformational comparison with thyroxine. Acta Crystallogr., Sect. B: Struct. Sci., v.B45, n.2, p.172-178, 1989.

COOK, W.J., BUGG, C.E. Crystal structures of azathioprine dihydrate and 6-methylmercaptopurine trihydrate. $J$. Pharm. Sci., v.64, n.2, p.221-225, 1975.

COSTA, J.; FRESNO, M.; GUZMÁN, L.; IGUAL, A.; OLIVA, J.; VIDAL, P.; PÉREZ, A.; PUJOL, M. Formas polimórficas del mebendazol: aspectos analíticos y toxicidad. Circ. Farm., v.49, n.312, p.415-426, 1991.

CROCKER, L.S.; MCCAULEY, J.A. Solubilities of losartan polymorphs. Pharmazie, v.52, n.1, p.72, 1997.

CSD. Cambridge Crystallographic Data Centre. version 5.33 of November 2011 with February 2012 and May 2012 updates. Available at: http://www.ccdc.cam.ac.uk/. Accessed on: May 2012. 
DAVIDSON, A.G.A. Multinational survey of the quality of carbamazepine tablets. Drug Dev. Ind. Pharm., v.21, n.19, p.2167-2186, 1995.

ESTEVES DE CASTRO, R.A.E.; CANOTILHO, J.; BARBOSA, R.M.; SILVA, M.R.; BEJA, A.M.; PAIXÃO, J.A.; REDINHA, S.J. Conformational isomorphism of organic crystals: racemic and homochiral Atenolol. Cryst. Growth Des., v.7, n.3, p.496-500, 2007.

DEROLlez, P.; DUdoGnON, E.; AFFOUARD, F.; DANĖDE, F.; CORREIA, N.T.; DESCAMPS, M. Ab initio structure determination of phase II of racemic ibuprofen by X-ray powder diffraction. Acta Crystallogr., Sect. B: Struct. Sci., v.66, n.1, p.76-80, 2010.

DESIRAJU, G.R. Chemistry beyond the molecule. Nature, v.412, n.6845, p.397-400, 2001.

DESIRAJU, G.R. Polymorphism: the same and not quite the same. Cryst. Growth Des., v.8, n.1, p.3-5, 2008.

DESIRAJU, G.R. Supramolecular synthons in crystal engineering - a new organic synthesis. Angew. Chem., Int. Ed. Engl., v.34, n.21, p.2311-2327, 1995.

DEXTER, D.D.; VAN DER VEEN, J.M. Conformations of penicillin G: crystal structure of procaine penicillin $\mathrm{G}$ monohydrate and a refinement of the structure of potassium penicillin G. J. Chem. Soc., Perkin Trans. 1, v.3, p.185-190, 1978.

DI MARTINO, P.; CONFLANT, P.; DRACHE, M.; HUVENNE, J.P.; GUYOT-HERMANN, A.M. Preparation and physical characterization of forms II and III of paracetamol. $J$. Therm. Anal., v.48, n.3, p.447-458, 1997.

DI MARTINO, P.; GUYOT-HERMANN, A.M.; CONFLANT, P.; DRACHE, M.; GUYOT, J.C. A new pure paracetamol for direct compression: the orthorhombic form. Int. J. Pharm., v.128, n.1/2, p.1-8, 1996.

DIAO, Y.; WHALEY, K.E.; HELGESON, M.E.; WOLDEYES, M.A.; DOYLE, P.S.; MYERSON, A.S.; HATTON, T.A.; TROUT, L.B. Gel-induced selective crystallization of polymorphs. J. Am. Chem. Soc., v.134, n.1, p.673-684, 2012.
DOLITZKY, B.Z.; WIZEL, S.; NISNEVICH, G.; RUKHMAN, I.; KAFTANOV, J. Amorphous and crystalline forms of losartan potassium and process for their preparation. US Pat. 2004/0006237, 8 Jan. 2004. 22 p.

DUDOGNON, E.; DANÈDE, F.; DESCAMPS, M.; CORREIA, N.T. Evidence for a new crystalline phase of racemic Ibuprofen. Pharm. Res., v.25, n.12, p.2853-2858, 2008.

EBERHARD, N.; BERND, D. Occurrence of paracrystalline forms of digoxin. Acta Pharm. Technol., v.29, n.1, p.1-8, 1983.

ERK, P.; HENGELSBERG, H.; HADDOW, M.F.; GELDER, R.V. The innovative momentum of crystal engineering. Cryst. Eng. Comm., v.6, p.474-483, 2004.

EUROPEAN Pharmapoeia. 6.ed. Strasbourg: Council of Europe, 2008. v.1, p.649.

EYJOLFSSON, R. Enalapril maleate form II: stabilization in a tablet formulation. Pharmazie, v.58, n.5, p.357, 2003.

EYJOLFSSON, R. Enalapril maleate polymorphs: instability of form II in a tablet formulation. Pharmazie, v.57, n.5, p.347-348, 2002.

FABBIANI, F.P.A.; ALLAN, D.R.; DAVID, W.I.F.; MOGGACH, S.A.; PARSONS, S.; PULHAM, C.R. Highpressure recrystallisation - a route to new polymorphs and solvates. Cryst. Eng. Comm., v.6, n.86, p.504-511, 2004.

FABBIANI, F.P.A.; ARLIN, J.-B.; BUTH, G.; DITTRICH, B.; FLORENCE, A.J.; HERBST-IRMER, R.; SOWA, $\mathrm{H}$. Intermolecular interactions, disorder and twinning in ciprofloxacin-2,2-difluoroethanol (2/3) and ciprofloxacinwater (3/14.5). Acta Crystallogr., Sect. C: Cryst. Struct. Commun., v.67, n.3, p.120-124, 2011.

FABBIANI, F.P.A.; DITTRICH, B. Redetermination and invariom refinement of 1-cyclopropyl-6-fluoro-4-oxo7-(piperazin-4-ium-1-yl)-1,4- dihydroquinoline-3carboxylate hexahydrate at $120 \mathrm{~K}$. Acta Crystallogr., Sect. E: Struct. Rep. Online, v.64, n.12, p.2354-2355, 2008.

FABBIANI, F.P.A.; DITTRICH, B.; FLORENCE, A.J.; GELBRICH, T.; HURSTHOUSE, M.B.; KUHS, W.F. Crystal structures with a challenge: high pressure crystallization of ciprofloxacin sodium salts and their recovery to ambient pressure. Cryst. Eng. Comm., v.11, n.7, p.1396-1406, 2009. 
FARMACOPEIA Brasileira. 5.ed. Brasília: Agência Nacional de Vigilância Sanitária, 2010. v.2, 904 p.

FDA. U.S. Food and Drug Administration. Guidance for Industry - ANDAs: Pharmaceutical Solid Polymorphism Chemistry, Manufacturing, and Controls Information, 2007. Available at: http://www.fda.gov/downloads/Drugs/ GuidanceComplianceRegulatoryInformation/Guidances/ ucm072866.pdf. Accessed on: Apr. 2012.

FDA. U.S. Food and Drug Administration. Neupro (rotigotine transdermal system) (Internet). United States of American: MedWatch The FDA Safety Information and Adverse Event Reporting Program, 2008. Available at: http:/www.fda. gov/Safety/MedWatch/SafetyInformation/SafetyAlertsfo rHumanMedicalProducts/ucm094861.htm. Accessed on: Apr. 2012.

FDA. U.S. Food and Drug Administration. Guidance for Industry - Regulatory Classification of Pharmaceutical Co-Crystals, 2013. Available at: http://www.fda.gov/ downloads/Drugs/Guidances/UCM281764.pdf. Accessed on: July 2013.

FEKETE, P. Pharmaceutical technology of tensiomin. Acta Pharm. Hung., v.67, n.4, p.113-121, 1997.

FERNÁNDEZ, D.; VEGA, D.; ELLENA, J.A.; ECHEVERRÍA, $\mathrm{G}$. Losartan potassium, a non-peptide agent for the treatment of arterial hypertension. Acta Crystallogr., C: Cryst. Struct. Commun., v.58, n.7, p.418-420, 2002.

FERREIRA, F.F.; ANTONIO, F.G.; ROSA, P.C.P.; PAIVASANTOS, C.O. Crystal structure determination of mebendazole form a using high-resolution synchrotron x-ray powder diffraction data. J. Pharm. Sci., v.99, n.4, p.1734-1744, 2010.

FILIP, L.A.; CAIRA, M.R.; SORIN, I.; FARCAS, S.I.; BOJITA, M.T. Triclinic polymorph of sulfasalazine. Acta Crystallogr., C: Cryst. Struct. Commun., v.57, n.4, p.435436, 2001.

FINKELSTEIN, N.; LIDOR-HADAS, R.; ARONHIME, J. Hidrate forms de alendronate sodium, processes for manufacture thereof, and pharmaceutical compositions thereof. US Pat. 6,696,601, 24 fev. 2004, 33 p.
FIORITTO, A.F.; BHATTACHAR, S.N.; WESLEY, J.A. Solubility measurement of polymorphic compounds via the pH-metric titration technique. Int. J. Pharm., v.330, n.1/2, p.105-113, 2007.

FLICKER, F.; EBERLE, V.A.; BETZ, G. Variability in commercial carbamazepine samples - impact on drug release. Int. J. Pharm., v.410, n.1/2, p.99-106, 2011.

FLORENCE, A.T.; SALOLE, E.G. Changes in crystallinity and solubility on comminution of digoxin and observations on spironolactone and estradiol. J. Pharm. Pharmacol., v.28, n.8, p.637-642, 1976.

FOSTER, A.; GORDON, K.; SCHMIERER, D.; SOPER, N.; WU, V.; RADER, T. Characterisation of two polymorphic forms of ranitidine-HCl. Internet J. Vib. Spectrosc., v.2, 1998. Available at: http://www.ijvs.com/volume2/edition2/ section2.html. Accessed on: Jun. 2012.

FOTAKI, N.; VERTIZONI, M. Biorelevant dissolution methods and their applications in in vitro-in vivo correlations for oral formulations. Open Drug Delivery J., v.4, n.2, p.2-13, 2010.

FROEHLICH, P.E.; GASPAROTTO, F.S. Mebendazol: identificação das formas polimórficas em diferentes matérias-primas e medicamentos (referência e genéricos) disponíveis no mercado nacional. Rev. Cienc. Farm. Basica Apl., v.26, n.3, p.205-210, 2005.

FUKUMORI, Y.; FUKUDA, T.; YAMAMOTO, Y.; SHIGITANI, Y.; HANYU, Y.; TAKEUCHI, Y.; SATO, N. Physical characterization of erythromycin dehydrate, anhydrate and amorphous solid and their dissolution properties. Chem. Pharm. Bull., v.31, n.11, p.4029-4039, 1983.

GALA, D.; DIBENEDETTO, D.J. Ethyl 4-(8-chloro-5,6dihydro-11h-benzo $(5,6)$ cyclohepta $(1,2-b)$ pyridin-11ylidene)-1-piperidene carboxylate polymorph. WO Pat.019322, 22 abr. 1999. 18 p.

GALVÁN-TEJADA, N.; BERNÈS, S.; CASTILLO-BLUM, S.E.; NÖTH, H.; VICENTE, R.; BARBA-BEHRENS, N. Supramolecular structures of metronidazole and its copper(II), cobalt(II) and zinc(II) coordination compounds. J. Inorg. Biochem., v.91, n.1, p.339-348, 2002. 
GELBRICH, T.; HURSTHOUSE, M.B. Systematic investigation of the relationships between 25 crystal structures containing the carbamazepine molecule or a close analogue: a case study of the XPac method. CrystEngComm, v.8, n.6, p.448460, 2006.

GILLON, A.L.; FEEDER, N.; DAVEY, R.J.; STOREY, R.; Hydration in molecular crystals - a Cambridge structural database analysis. Cryst. Growth Des., v.3, n.5, p.663-673, 2003.

GO, K.; KARTHA, G.; CHEN, J.P. Structure of digoxin. Acta Crystallogr., Sect. C: Cryst. Struct. Commun., v.36, n.8, p.1811-1819, 1980.

GOLDBEK, G.; PIDCOK, E.; GROOM, C. Solid form informatics for pharmaceuticals and agrochemicals: knowledge-based substance development and risk assessment. Cambridge Crystallographic Data Centre, p.1-8, 2011. Available at: http:/www.ccdc.cam.ac.uk/Lists/ ResourceFileList/Solid\%20Form\%20Informatics\%20.pdf. Accessed on: Oct. 2013.

GRANT, D.J.W.; BYRN, S.R. A timely re-examination on drug polymorphism in pharmaceutical development and regulation. Adv. Drug Delivery Rev., v.56, n.3, p.237-239, 2004.

GRIESSER, U.J. The importance of solvates. In: HILFIKER, R. (Ed.). Polymorphism in pharmaceutical industry. Weinheim: Wiley-VCH, 2006. cap.8, p.211-230.

GROOFF, D.; DE VILLIERS, M.M.; LIEBENBERG, W. Thermal methods for evaluating polymorphic transitions in nifedipine. Thermochim. Acta, v.454, n.1, p.33-42, 2007.

GRZESIAK, A.; LANG, M.; KIM, K.; MATZGER, A. Comparison of the four anhydrous polymorphs of carbamazepine and the crystal structure of form I. J. Pharm. Sci., v.92, n.11, p.2260-2271, 2003.

GUGUTA, C.; EEUWIJK, I.; SMITS, J.M.M.; DE GELDER, R. Structural diversity of ethinyl estradiol solvates. Cryst. Growth Des., v.8, n.3, p.823-831, 2008.

GUNN, E.; GUZEI, I.A.; CAI, T.; YU, L. Polymorphism of Nifedipine: crystal structure and reversible transition of the metastable $\beta$ polymorph. Cryst. Growth Des., v.12, n.4, p.2037-2043, 2012.
HAISA, M.; KASHINO, S.; MAEDA, H. The orthorhombic form of $p$-hydroxyacetanilide. Acta Crystallogr., Sect. B: Struct. Crystallogr. Cryst. Chem., v.30, n.10, p.2510-2512, 1974.

HANCOCK, B.C.; PARKS, M. What is the true solubility advantage for amorphous pharmaceuticals? Pharm. Res., v.17, n.4, p.397-404, 2000.

HAOMING, H.; KUILI, Z. The phenomenon of polymorphism of captopril. Acta Pharmacol. Sin., v.20, n.8, p.623-627, 1985.

HARRIS, R.K.; GHI, P.Y.; PUSCHMANN, H.; APPERLEY, D.C.; GRIESSER, U.J.; HAMMOND, R.B.; MA, C.; ROBERTS, K.J.; PEARCE, G.J.; YATES, J.R.; PICKARD, C.J. Structural studies of the polymorphs of carbamazepine, its dihydrate, and two solvates. Org. Process Res. Dev., v.9, n.6, p.902-910, 2005.

HARTAUER, K.J.; MILLER, E.S.; GUILLORY, J.K. Diffuse reflectance infrared Fourier transform spectroscopy for the quantitative analysis of mixtures of polymorphs. Int. J. Pharm., v.85, n.1/2, p.163-174, 1992.

HEMPEL, A.; CAMERMAN, N.; MASTROPAOLO, D.; CAMERMAN, A. Ranitidine hydrochloride, a polymorphic crystal form. Acta Crystallogr., C: Cryst. Struct. Commun., v.56, n.8, p.1048-1049, 2000.

HIMES, V.L.; MIGHELL, A.D.; DE CAMP, W.H. Structure of carbamazepine: $5 H$-dibenz $(b, f)$ azepine-5-carboxamide. Acta Crystallogr., Sect. B: Struct. Crystallogr. Cryst. Chem., v.37, n.12, p.2242-2245, 1981.

HOWARD, S.T.; HURSTHOUSE, M.B.; LEHMANN, C.W.; POYNER, E.A. Experimental and theoretical determination of electronic properties in L-dopa. Acta Crystallogr., Sect. B: Struct. Sci., v.51, n.3, p.328-337, 1995.

HUSAK, M.; KRATOCHVÍL, B.; JEGOROV, A.; BRUS, J.; MAIXNER, J.; ROHLICEK, J. Simvastatin: structure solution of two new low-temperature phases from synchrotron powder diffraction and ss-NMR. Struct. Chem., v.21, n.3, p.511-518, 2010.

ICH. Q6A: Test procedures and acceptance criteria for new drug substances and new drug products: chemical substances. Genebra: ICH, 1999. Available at: http://www.ich.org/ products/guidelines/quality/article/qualityguidelines.html. Acsessed on: July 2012. 
JAVADZADEH, Y.; MOHAMMADI, A.; KHOEI, N.S.; NOKH, A. Improvement of physicomechanical properties of carbamazepine by recrystallization at different $\mathrm{pH}$ values. Acta Pharm., v.59, n.2, p.187-197, 2009.

KANG, Y.; LI, Q.; LIU, Y. Deuterated acid salts of oseltamivir. WO Pat. n.088648, 05 Jul. 2012. 23p.

KANTERS, J.A.; SCHOUTEN, A.; STERK, G.J.; JONG, M.H. Crystallographic study of three coronary vasodilators of the nitrate ester type: 1,4-trans-cyclohexanedimethanol dinitrate, 1,4:3,6-dianhydro-d-glucitol-2,5-dinitrate and 1,4:3,6-dianhydro-d-glucitol-2-mononitrate. J. Mol. Struct., v.298, p.113-120, 1993.

KARPINSKI, P.H. Polymorphism of active pharmaceutical ingredients. Chem. Eng. Technol., v.29, n.2, p.233-237, 2006.

KASIM, N.A.; WHITEHOUSE, M.; RAMACHANDRAN, C.; BERMEJO, M.; LENNERNÄS, H.; HUSSAIN, A.S.; JUNGINGER, H.E.; STAVCHANSKY, S.A.; MIDHA, K.K.; SHAH, V.P.; AMIDON, G.L. Molecular properties of WHO essential drugs and provisional biopharmaceutical classification. Mol. Pharmaceutics, v.1, n.1, p.85-96, 2004.

KENNEDY,A.R.; OKOTH, M.O.; SHEEN, D.B.; SHERWOOD, J.N.; TEAT, S.J.; VRCELJ, R.M. Cephalexin: a channel hydrate. Acta Crystallogr., Sect. C: Cryst. Struct. Commun., v.59, n.11, p.650-652, 2003.

KHUNT, M.D.; KESHAVA, N.K.R.; MADDURI, S.R.; SRIPATHI, S.S.; VALLURI, S. Preparation of loratadine form I. US Pat n.0194823, 14 Aug. 2008. 12 p.

KIANG, Y.H.; HUQ, A.; STEPHENS, P.W.; XU, W. Structure determination of enalapril maleate form II from highresolution X-ray powder diffraction data. J. Pharm. Sci., v.92, n.9, p.1844-1853, 2003.

KIECZYKOWSKI, G.R.; MELILLO, D.G.; JOBSON, R.B. Process for preparing 4-amino-1-hydroxybutylidene-1, 1- biphosphonic acid or salts thereof. US Pat. n.4,922,007, 1 May 1990. 5p.

KIPOUROS, K.; KACHRIMANIS, K.; NIKOLAKAKIS, I.; MALAMATARIS, S. Quantitative analysis of less soluble form IV in commercial carbamazepine (form III) by diffuse reflectance fourier transform spectroscopy (DRIFTS) and lazy learning algorithm. Anal. Chim. Acta, v.550, n.1/2, p.191-198, 2005.
KLEIN, C.L.; CONRAD III, J.M. Structure of a new crystallographic form of chlorpromazine hydrochloride hemihydrate. Acta Crystallogr., Sect. C: Cryst. Struct. Commun., v.42, n.8, p.1083-1085, 1986.

KLEIN, C.L.; LEAR, J.; O’ROURKE, S.; WILLIAMS, S.; LIANG, L. Crystal and molecular structures of tricyclic neuroleptics. J. Pharm. Sci., v.83, n.9, p.1253-1256, 1994.

KOBAYASHI, Y.; ITO, S.; ITAI, S.; YAMAMOTO, K. Physicochemical properties and bioavailability of carbamazepine polymorphs and dehydrate. Int. J. Pharm., v.193, n.2, p.137-146, 2000.

KOGAN, A.; POPOV, I.; UVAROV, V.; COHEN, S.; ASERIN, A.; GART, I.N. Crystallization of carbamazepine pseudopolymorphs from nonionic microemulsions. Langmuir, v.24, n.3, p.722-733, 2008.

KOETZLE, T.F.; WILLIAMS, G.J.B. The crystal and molecular structure of the antifolate drug trimethoprim (2,4-Diamino-5-(3,4,5-trimethoxybenzyl)pyrimidine): a neutron diffraction study. J. Am. Chem. Soc., v.98, n.8, p.2074-2078, 1976.

KRISTL, A.; SRČIČ , S.; VREČER, F.; ŠUŠTAR, B.; VOJNOVIC, D. Polymorphism and pseudopolymorphism: influencing the dissolution properties of the guanine derivative acyclovir. Int. J. Pharm., v.139, n.1/2, p.231235, 1996.

LAKE, O.A.; OLLING, M.; BARENDS, D.M. In vitro/in vivo correlations of dissolution data of carbamazepine immediate release tablets with pharmacokinetic data obtained in healthy volunteers. Eur. J. Pharm. Biopharm., v.48, n.1, p.13-19, 1999.

LANG, M.; KAMPF, J.W.; MATZGER, A.J. Form IV of carbamazepine. J. Pharm. Sci., v.91, n.4, p.1186-1190, 2002.

LEE, A.Y.; ERDEMIR, D.; MYERSON, A.S. Crystal polymorphism in chemical process development. Annu. Rev. Chem. Biomol. Eng., v.2, p.259-280, 2011.

LEECH, C.K.; FABBIANI, F.P.A.; SHANKLAND, K.; DAVID, W.I.F.; IBBERSON, R.M. Accurate molecular structures of chlorothiazide and hydrochlorothiazide by joint refinement against powder neutron and X-ray diffraction data. Acta Crystallogr., Sect. B, v.64, n.1, p.101-107, 2008. 
LEGENDRE, A.O.; SILVA, L.R.R.; SILVA, D.M. Solid state chemistry of the antibiotic doxycycline: structure of the neutral monohydrate and insights into its poor water solubility. Cryst. Eng. Comm., v.14, n.7, p.2532-2540, 2012.

LIEBENBERG, W.; DEKKER, T.G.; LÖTTER, A.P.; VILLIERS, M.M. Identification of the mebendazole polymorphic form present in raw materials and tablets available in South Africa. Drug Dev. Ind. Pharm., v.24, n.5, p.485-488, 1998.

LINDENBERG, M.; KOPP, S.; DRESSMAN, J.B. Classification of orally administered drugs on the World Health Organization model list of essential medicines according to the Biopharmaceutics Classification System. Eur. J. Pharm. Biopharm., v.58, n.2, p.265-278, 2004.

LISGARTEN, J.N.; PALMER, R.A.; SALDANHA, J.W. Crystal and molecular structure of 5-carbamyl-5H-dibenzo $(b, f)$ azepine. J. Crystallogr. Spectrosc. Res., v.19, n.4, p.641$649,1989$.

LLINÀS, A.; GOODMAN, J.M. Polymorph control: past, present and future. Drug Disc. Today, v.13, n.5/6, p.198$210,2008$.

LOWES, M.M.; CAIRA, M.R.; LÖTTER, A.P.; VAN DER WATT, J.G. Physicochemical properties and X-ray structural studies of the trigonal polymorph of carbamazepine. $J$. Pharm. Sci., v.76, n.9, p.744-752, 1987.

LULLA, A.; MAHOTRA, G.; RAO, D.R.; KANKAN, R.N.; CHAUDHARY, A. Crystalline levosalbutamol sulphate (Form II). EP Pat. 2.311.793, 20 abr. 2011. 29 p.

LUTKER, K.M.; QUINONES, R.; XU, J.; RAMAMOORTHY, A.; MATZGER, A.J. Polymorphs and hydrates of acyclovir. J. Pharm. Sci., v.100, n.3, p.949-963, 2011.

RUSTICHELLI, C.; GAMBERINI, G.; FERIOLI, V.; GAMBERINI, M.C.; FICARRA, R.; TOMMASINI, S. Solid-state study of polymorphic drugs: carbamazepine. $J$. Pharm. Biomed. Anal., v.23, n.1, p.41-54, 2000.

MADAN, T.; KAKKAR, A.P. Preparation and characterization of ranitidine-HC1 crystals. Drug Dev. Ind. Pharm., v.20, n.9, p.1571-1588, 1994.
MAFRA, L.; SANTOS, S.M.; SIEGEL, R; ALVES, I.; PAZ, F.A.A.; DUDENKO, D.; SPIESS, H.W. Packing interactions in hydrated and anhydrous forms of the antibiotic ciprofloxacin: a solid-state NMR, X-RAY diffraction, and computer simulation study. J. Am. Chem. Soc., v.134, n.1, p.71-74, 2012.

MAGGIO, R.M.; CASTELLANO, P.M.; KAUFMAN, T.S. PCA-CR analysis of dissolution profiles: a chemometric approach to probe the polymorphic form of the active pharmaceutical ingredient in a drug product. Int. J. Pharm., v.378, n.1, p.187-193, 2009.

MARTINS, F.T.; NEVES, P.P.; ELLENA, J.; CAMÍ, G.E.; BRUSAU, E.V.; NARDA, G.E. Intermolecular contacts influencing the conformational and geometric features of the pharmaceutically preferred mebendazole polymorph C. J. Pharm. Sci., v.98, n.7, p.2336-2344, 2009.

MASTROPAOLO, D.; CAMERMAN, A.; CAMERMAN, N. Folic acid: crystal structure and implications for enzyme binding. Science, v.210, n.4467, p.334-336, 1980.

MATSUDA, Y.; TATSUMI, E. Physicochemical characterization of furosemide modifications. Int. J. Pharm., v.60, n.1, p.1126, 1990 .

MAURY, L.; RAMBAUDB, J.; PAUVERT, B.; LASSERREG, Y.; BERGE, G.; AUDRAN, M. Étude physico-chimique, spectres de vibration et structure du sulfamethoxazole. Can. J. Chem., v.63, n.11, p.3012-3018, 1985.

MCDOWELL, J.J.H. The crystal and molecular structure of chlorpromazine. Acta Crystallogr., Sect. B: Struct. Crystallogr. Cryst. Chem., v.25, n.11, p.2175-2181, 1969.

MCGREGOR, P.A.; ALLAN, D.R.; PARSONS, S.; PULHAM, C.R. Preparation and crystal structure of a trihydrate of paracetamol. J. Pharm. Sci., v.91, n.5, p.1308-1011, 2002.

MEYER, M.C.; STAUGHN, A.B.; MHATRE, R.M.; SHAH, V.P.; WILLIAMS, R.L.; LESKO, L.J. The relative bioavailability and in vivo-in vitro correlations for four marketed carbamazepine tablets. Pharm. Res., v.15, n.11, p.1787-1791, 1998.

MEYER, M.C.; STRAUGHN, A.B.; JARVI, E.J.; WOOD, G.C.; PELSOR, F.R.; SHAH, V.P. The bioinequivalence of carbamazepine tablets with a history of clinical failures. Pharm. Res., v.9, n.12, p.1612-1616, 1992. 
MIROSHNYK, I.; KHRIACHTCHEV, L.; MIRZA, S.; RANTANEN, J.; HEINÄMÄKI, J.; YLIRUUSI, J. Insight into thermally induced phase transformations of erythromycin a dihydrate. Cryst. Growth Des., v.6, n.2, p.369-374, 2006.

MITTAPALLI, P.K.; SURESH, B.; HUSSAINI, S.S.Q.; RAO, Y.M.; APTE, S. Comparative in vitro study of six carbamazepine products. AAPS Pharm. Sci. Tech., v.9, n.2, p.357-365, 2008.

MOHAMED, S.; TOCHER, D.A.; VICKERS, M.; KARAMERTZANIS, P.G. Salt or cocrystal? a new series of crystal structures formed from simple pyridines and carboxylic acids. Cryst. Growth Des., v.9, n.6, p.28812889, 2009.

MONTEJO-BERNARDO, J.M.; GARCÍA-GRANDA, S. New solvated formo $f$ the antibiotic azithromycin: Clues about the role of the water retained inside the crystal. $Z$. Kristallogr, v.222, n.9, p.492-497, 2009.

MOSTAD, A.; OTTERSEN, T.; RǾMMING, C. On the struture of L-DOPA(2S-3-dihydroxyphenyl)alanine). Acta Chem. Scand., v.25, n.10, p.3549-3560, 1971.

MOSTAD, A.; OTTERSEN, T.; RǾMMING, C. X-ray crystal structure determination of 3,4- Dihydroxyphenylalanine (LDOPA). Acta Chem. Scand., v.24, n.5, p.1864-1865, 1970.

MOULTON, B.; ZAWOROTKO, M.J. From molecules to crystal engineering: supramolecular isomerism and polymorphism in network solids. Chem. Rev., v.101, n.33, p.1629-1658, 2001.

NAUMOV, D.Y.; VASILCHENKO, M.A.; HOWARD, J.A.K. The Monoclinic form of acetaminohen at $150 \mathrm{~K}$. Acta Crystallogr., Sect. C: Cryst. Struct. Commun., v.54, n.5, p.653-655, 1998.

NEUMAN, P.A.; GILLIER, H.; AVENEL, D.; PERRET, G. $\alpha$-Méthyl-dopa, $\mathrm{C}_{10} \mathrm{H}_{13} \mathrm{NO}_{4} \cdot 1,5 \mathrm{H}_{2} \mathrm{O}$. Acta Crystallogr., Sect. C: Cryst. Struct. Commun., v.40, n.12, p.2124-2126, 1984.

NGOOI, T.K.; MCGOLRICK, J.D.; ANTCZAK, C.; TINDALL, J.L.A. Preparation of form 1 ranitidine hydrochloride. US Pat. 5.338.871, Aug 16, 1994. 3p.
NICHOLS, G.; FRAMPTON, C.S. Physicochemical characterization of the orthorhombic polymorph of paracetamol crystallized from solution. J. Pharm. Sci., v.87, n.6, p.684-693, 1998.

NOKHODCHI, A.; BOLOURTCHIAN, N.; DINARVAND, R.; Crystal modification of phenytoin using different solvents and crystallization conditions. Int. J. Pharm., v.250, n.1, p.85-97, 2003.

NUNN, T.; WILLIAMS, J. Formulation of medicines for children. Br. J. Clin. Pharmacol., v.59, n.6, p.674-676, 2005.

OHISHI, H.; IN, Y.; ISHIDA, T; INOUE, M.; SATO, F.; OKITSU M.; OHNO, T. Structure of methoxy-2-\{(4methoxy-3,5-dimethyl-2-pyridinylmethyl)sulfinyl $\}-1 H$ benzimidazole (omeprazole). Acta Crystallogr., Sect. C: Cryst. Struct. Commun., v.45, n.12, p.1921-1923, 1989.

OTSUKA, M.; KANENIWA, N. Dehydration of cephalexin hydrates. Chem. Pharm. Bull., v.31, n.3, p.1021-1029, 1983.

OTSUKA, M.; ONOE, M.; MATSUDA, Y. Physicochemical characterization of phenobarbital polymorphs and their pharmaceutical properties. Drug Dev. Ind. Pharm., v.20, n.8, p.1453-1470, 1994

OTSUKA, M.; ONOE, M.; MATSUDA, Y. Physicochemical stability of phenobarbital polymorphs at various levels of humidity and temperature. Pharm. Res., v.10, n.4, p.577$582,1993$.

PABÓN, C.V.; FRUTOS, P.; LASTRES, J.L.; FRUTOS, G. Application of differential scanning calorimetry and $\mathrm{X}$-ray powder diffraction to the solid-state study of metoclopramide. J. Pharm. Biomed. Anal., v.15, n.1, p.131138, 1996.

PALACIO, M.A.; CUFFINI, S.; BADINI, R.; KARLSSON, A.; PALACIOS, S.M. Solid-state characterization of two polymorphic forms of $R$-albuterol sulfate. J. Pharm. Biomed. Anal., v.43, n.4, p.1531-1534, 2007.

PARK, H.J.; KIM, M.; KIM, J.; CHO, W.; PARK, J.; CHA, K.; YOUNG-SHIN, K.; SUNG-JOO, H. Solid-state carbon NMR characterization and investigation of intrinsic dissolution behavior of fluconazole polymorphs, anhydrate forms I and II. Chem. Pharm. Bull., v.58, n.9, p.1243-1247, 2010 . 
PARK, H.J.; KIM, M.; LEE, S.; KIM, J.; WOO, J.; PARK, J.; HWANG, S.J. Recrystallization of fluconazole using the supercritical antisolvent (SAS) process. Int. J. Pharm., v.328, n.2, p.152-160, 2007.

PARKIN, A.; PARSONS, S.; PULHAM, C.R. Paracetamol monohydrate at 150 K. Acta Crystallogr., Sect. E: Struct. Rep. Online, v.E58, n.12, p.O1345-O1347, 2002.

PHADNIS, N.V.; CAVATUR, R.K.; SURYANARAYANAN, R. Identification of drugs in pharmaceutical dosage form by X-ray powder diffractometry. J. Pharm. Biomed. Anal., v.15, n.7, p.929-943, 1997.

PEDERSEN, M.; PEDERSEN, S.; SØRENSEN, A.M. Polymorphism of miconazole during preparation of solid systems of the drug and fl-cyclodextrins. Pharm. Acta Helv., v.68, n.1, p.43-47, 1993.

PEETERS, O.M.; BLATON, N.M.; AESCHLIMANN, C.; GAL, J. (+)-1-\{(2S)-2-(2,4-Dichlorophenyl)-2-((2,4dichlorophenyl)methoxy)ethyl $\}-1 H$-imidazole mononitrate ((+)-(S)-miconazole nitrate). Acta Crystallogr., Sect. E: Struct. Rep. Online, v.60, n.3, p.365-366, 2004.

PEETERS, O.M.; BLATON, N.M.; GERBER, J.G.; GAL, J. (+)-cis-1-Acetyl-4-(4-\{((2R,4S)-2-(2,4-dichlorophenyl)2-(1H-imidazol-1-ylmethyl)-1,3-dioxolan-4yl)methoxy phenyl)piperazine $((2 R, 4 S)-(+)$-ketoconazole $)$. Acta Crystallogr., Sect. E: Struct. Rep. Online, v.60, n.3, p.367369, 2004.

PEETERS, O.M.; BLATON, N.M.; DE, RANTER, C.J. cis-1-Acetyl-4-(4-\{(2-(2,4 dichlorophenyl)-2-(1H-1imidazolylmethyl)-1,3-dioxolan-4yl)methoxy \} phenyl) piperazine: ketoconazole: a crystal structure with disorder. Acta Crystallogr., Sect. B, v.35, p.2461-2464, 1979.

PETERSON, M.L.; HICKEY, M.B.; ZAWOROTKO, M.J.; ALMARSSON, Ö. Expanding the scope of crystal form evaluation in pharmaceutical science. J. Pharm. Pharm. Sci., v.9, n.3, p.317-326, 2006.

PETERSON, M.L.; MORISSETTE, S.L.; MCNULTY, C.; GOLDSWEIG, A.; SHAW, P.; LEQUESNE, M.; MONAGLE, J.; ENCINA, N.; MARCHIONNA, J.; JOHNSON, A.; GONZALEZ-ZUGASTI, J.; LEMMO, A.V.; ELLIS, S.J.; CIMA, M.J.; ALMARSSON, O. Iterative high-throughput polymorphism studies on acetaminophen and an experimentally derived structure for form III. J. Am. Chem. Soc., v.124, n.37, p.10958-10959, 2002.
PHADNIS, N.V.; CAVATUR, R.K.; SURYANARAYANAN, R. Identification of drugs in pharmaceutical dosage forms by X-ray powder diffractometry. J. Pharm. Biomed. Anal., v.15, n.7, p.929-943, 1997.

PLATTEAU, C.; LEFEBVRE, J.; HEMON, S.; BAEHTZ, C.; DANEDE, F.; PREVOST, D. Structure determination of forms I and II of phenobarbital from X-ray powder diffraction. Acta Crystallogr., B: Struct. Sci., v.61, n.1, p.80-88, 2005.

BRASIL. Portal da Saúde. SUS. Rede própria da farmácia popular do Brasil. Available at: http://portal.saude.gov.br/ portal/saude/area.cfm?id_area=1095. Accessed on: Mar 2012.

PRANZO, M.B.; CRUICKSHANK, D.; CORUZZI, M.; CAIRA, M.R.; BETTINI, R. Enantiotropically related albendazole polymorphs. J. Pharm. Sci., v.99, n.9, p.3731$3742,2010$.

PRASANNA, M.D.; ROW, T.N.G. Weak interactions involving organic fluorine: analysis of structural motifs in flunazirine and haloperidol. J. Mol. Struct., v.562, n.1-3, p.55-61, 2001.

PRÉCIGOUX, G.; GEOFFRE, S.; LEROY, F. N-(1Ethoxycarbonyl-3-phenylpropyl)-l-alanyl-l-proliniumhydrogen maleate (1/1), enalapril (MK-421). Acta Crystallogr., Sect. C: Cryst. Struct. Commun., v.42, n.8, p.1022-1024, 1986.

PRICE, C.P.; GRZESIAK, A.L.; MATZGER, A.J. Crystalline polymorph selection and discovery with polymer heteronucleic. J. Am. Chem. Soc., v.127, n.15, p.5512$5517,2005$.

PRUSINER, P.; SUNDARALINGAM, M. Stereochemistry of nucleic acids and their constituents. XXIX. Crystal and molecular structure of allopurinol, a potent inhibitor of xanthine oxidase. Acta Crystallogr., B: Struct. Crystallogr. Cryst. Chem., v.28, n.7, p.2148-2152, 1972.

PUDIPEDDI, M.; SERAJUDDIN, A.T.M. Trends in solubility of polymorphs. J. Pharm. Sci., v.94, n.5, p.929-939, 2005.

PUROHIT, R.; VENUGOPALAN, P. Polymorphism: an overview. Resonance, v.14, n.9, p.882-893, 2009.

QUIST, F.; MOONEY, J.; KAKKAR, A.K. Self-assembled monolayers: solidification of carbamazepina in form II at an interface. Colloids Surf., B, v.62, n.2, p.319-323, 2008. 
RAO, D.R.; KANKAN, R.N.; CHAUDHARY, A. Crystalline levosalbutamol sulphate and polymorphic forms thereof. US Pat. 7.915.451B2, Mar 29, 2011. 12 p.

RAW, A.S.; FURNESS, M.S.; GILL, D.S.; ADAMS, R.C.; HOLCOMBE JR., F.O.; YU, L.X. Regulatory considerations of pharmaceutical solid polymorphism in Abbreviate New Drug Applications (ANDAs). Adv. Drug Delivery Rev., v.56, n.3, p.397-414, 2004.

REBOUL, J.P.; CRISTAU, B.; SOYFER, J.C.; ASTIER, J.P. $5 H$-Dibenz $(b, f)$ azépinecarboxamide-5 (carbamazépine). Acta Crystallogr., B: Struct. Crystallogr. Cryst. Chem., v.37, n.10, p.1844-1848, 1981.

REISCH, J.; ZAPPEL, J.; HENKEL, G.; EKIZ-GÜCER, N. Photochemische Studien, 65. Mitt.: Untersuchungen zur Photostabilität von Ethisteron und Norethisteron sowie deren Kristallstrukturen. Monatsh. Chem., v.124, n.11/12, p.1169-1175, 1993.

ROBERTSON, D.W.; JONES, N.D.; SWARTZENDRUBER, J.K.; YANG, K.S.; WONG, D.T. Molecular structure of fluoxetine hydrochloride, a highly selective serotoninuptake inhibitor. J. Med. Chem., v.31, n.1, p.185-189, 1988.

RODRIGUEZ-CAABEIRO, F.; CRIADO-FORNELIO, A.; JIMENEZ- GONZALEZ, A.; GUZMAN, L.; IGUAL, A.; PÉREZ, A.; PUJOL, M. Experimental chemotherapy and toxicity in mice of three mebendazole polymorphic forms. Chemotherapy, v.33, n.4, p.266-271, 1987.

RUSTICHELLI, C.; GAMBERINI, G.; FERIOLI, V.; GAMBERINI, SCHULTHEISS, N.; NEWMAN, A. Pharmaceutical cocrystals and their physicochemical properties. Cryst. Growth Des., v.9, n.6, p.2950-2967, 2009.

ŠEHIĆ, S.; BETZA, G.; HADŽIDEDIĆ, Š.; EL-ARINI, S.K.; LEUENBERGER, H. Investigation of intrinsic dissolution behavior of different carbamazepine samples. Int. J. Pharm., v.386, n.1-2, p.77-90, 2010.

SHANKLAND, N.; FLORENCE, A.J.; COX, P.J.; SHEEN, D.B.; LOVE, S.W.; STEWART, N.S.; WILSON C.C. Crystal morphology of ibuprofen predicted from singlecrystal pulsed neutron diffraction data. Chem. Commun., v.7, n.7, p.855-856, 1996.

SHEN, J.; LEE, D.; MCKEAG, R.G. Bioequivalence of two forms of ranitidine. N. Z. Pharm., v.15, n.10, p.24-25, 1995.
SHIKII, K.; SEKI, H.; SAKAMOTO, S.; SEI, Y.; UTSUMI, H.; YAMAGUCHI, K. Intermolecular hydrogen bonding of steroid compounds: PFG NMR diffusion study, cold-spray ionization (CSI)-MS and X-Ray analysis. Chem. Pharm. Bull., v.53, n.7, p.792-795, 2005.

SHINGAL, D.; CURATOLO, W. Drug polymorphism and dosage form design: a practical perspective. Adv. Drug Delivery Rev., v.56, n.3, p.335-337, 2004.

SNIDER, D.A.; ADDICKS, W.; OWENS, W. Polymorphism in generic drug product development. Adv. Drug Delivery Rev., v.56, n.3, p.391-395, 2004.

SOHN, Y.-T.; KIM, S.H. Polymorphism and pseudopolymorphism of Acyclovir. Arch. Pharmacal Res., v.31, n.2, p.231-234, 2008.

SOHN, Y.-T.; UM, B.-Y. Dissolution of glibenclamide polymorphs. Yakche Hakhoechi, v.27, n.3, p.233-239, 1997.

STEPHENSON, G.A.; GROLEAU, E.G.; KLEEMANN, R.L.; XU, W.; RIGSBEE, D.R. Formation of isomorphic desolvates: creating a molecular vacuum. J. Pharm. Sci., v.87, n.5, p.536-542, 1998

STEPHENSON, G.A.; STOWELL, J.G.; TOMA, P.H.; PFEIFFER, R.R.; BYRN, S.R. Solid-state investigations of Erythromycin A dihydrate: structure, NMR spectroscopy, and Hygroscopicity. J. Pharm. Sci., v.86, n.11, p.12391244, 1997.

STONE, K.H.; LAPIDUS, S.H.; STEPHENS, P.W. Implementation and use of robust refinement in powder diffraction in the presence of impurities. J. Appl. Crystallogr., v.42, n.3, p.385-391, 2009.

SUITCHMEZIAN, V.; JESS, I.; NÄTHER, C. Private crystallographic data deposited at the Cambridge Crystallographic Data Centre available on request quoting the deposition number CCDC 681818, 2008.

SWANEPOEL, E.; LIEBENBERG, W.; DE VILLIERS, M.M. Quality evaluation of generic drugs by dissolution test: changing the USP dissolution medium to distinguish between active and non-active mebendazole polymorphs. Eur. J. Pharm. Biopharm., v.55, n.3, p.345-349, 2003.

TAKASUKA, M.; NAKAI, H. IR and Raman spectral and X-ray structural studies of polymorphic forms of sulfamethoxazole. Vib. Spectrosc., v.25, n.2, p.197-204, 2001. 
TAWASHI, R. Aspirin: dissolution rates of two polymorphics forms. Science, v.160, n.3823, p.76, 1968.

TESSLER, L.; GOLDBERG, I. Losartan, an antihypertensive drug. Acta Crystallogr., Sect. E: Struct. Rep. Online, v.60, n.10, p.1830-1832, 2004.

THAYER, A.M. Finding solutions: custom manufacturers take on drug solubility issues to help pharmaceutical firms move products through development. Chem. Eng. News, v.88, n.22, p.13-18, 2010.

TSRL inc. Therapeutic System Research Laboratories. BCS (Biopharmaceutics Classification System).Avaiable at: http://69.20.123.154/services/bcs/search.cfm. Acessed on: 16 Jul. 2012.

TUREL, I.; GOLOBIC, A. Crystal structure of ciprofloxacin hydrochloride 1.34-hydrate. Anal. Sci., v.19, n.3, p.329330, 2003.

TUTUGHAMIARSO, M.; WAGNER, G.; EGERT, E. Cocrystals of 5-fluorocytosine. I. Coformers with fixed hydrogen-bonding sites. Acta Crystallogr., B: Struct. Sci., v.68, n.4, p.431-443, 2012.

UEKAMA, K.; IKEGAMI, K.; WANG, Z.; HORIUCHI, Y.; HIRAYAMA, F. Inhibitory effect of 2-hydroxypropyl-betacyclodextrin on crystal-growth of nifedipine during storage: superior dissolution and oral bioavailability compared with polyvinylpyrrolidone K-30. J. Pharm. Pharmacol., v.44, n.2, p.73-78, 1992.

UNITED States Pharmacopeia USP35; National Formulary NF30. Rockville: United States Pharmacopeial Convention, 2012. v.1-3, 5089 p.

UNITED States Pharmacopeia USP34; National Formulary NF29. Rockville: United States Pharmacopeial Convention, 2011. v.2-3.

VARIANKAVAL, N.E.; JACOB, K.I.; DINH, S.M. Crystallization of betaestradiol in an acrylic transdermal drug delivery system. J. Biomed. Mater. Res., v.44, n.4, p.397-406, 1999.

VARUGHESE, S.; KIRAN, M.S.R.N.; SOLANKO, K.A.; BOND, A.D.; RAMAMURTY, U.; DESIRAJU, G.R. Interaction anisotropy and shear instability of aspirin polymorphs established by nanoindentation. Chem. Sci., v.2, n.11, p.2236-2242, 2011.
VEGA, D.; BAGGIO, R.; GARLAND, M.T. Monosodium 4-Amino-1-hydroxy-1,1-butanediyldiphosphonate Trihydrate (Alendronate). Acta Crystallogr., Sect. C: Cryst. Struct. Commun., v.52, n.9, p.2198-2201, 1996.

VILLIERS, M.M.; WATT, J.G.; LÖTTER, A.P. Kinetic study of the solid-state photolytic degradation of two polymorphic forms of furosemide. Int. J. Pharm., v.88, n.1/3, p.275-283, 1992.

VISHWESHWAR, P.; MCMAHON, J.A.; OLIVEIRA, M.; PETERSON, M.L.; ZAWOROTKO, M.J. The predictably elusive form II of aspirin. J. Am. Chem. Soc., v.127, n.48, p.16802-1603, 2005.

VOGT, M.; DERENDORF, H.; KRÄMER, J.; JUNGINGER, H.E.; MIDHA, K.K.; SHAH, V.P.; STAVCHANSKY, S.; DRESSMAN, J.B.; BARENDS, D.M. Biowaiver monographs for immediate release solid oral dosage forms: Prednisone. J. Pharm. Sci., v.96, p.1480-1489, 2007.

VON RAUMER, M.; DANNAPPEL, J.; HILFIKER, R. Polymorphism, salts, and crystallization. The relevance of solid-state development. Chim. Oggi, v. 24, n. 1, p. 41-44, 2006.

WANG, M.; RUTLEDGE, G.C.; MYERSON, A.S.; TROUT, B.L. Production and characterization of carbamazepine nanocrystals by electrospraying for continuous pharmaceutical manufacturing. J. Pharm. Sci., v.10, n.3, p.1178-1188, 2012.

WEHNER, H.L.; SPIERING, H.; RITTER, G. Polymorphism of anhydrous ferrous sulfate. Solid State Commun., v.20, n.9, p.831-835, 1976.

WU, C.; BENET, L.Z. Predicting drug disposition via application of BCS: transport/absorption/elimination interplay and development of a biopharmaceutics drug disposition classification system. Pharm. Res., v.22, n.1, p.11-23, 2005.

WU, L.S.; GERARD, C.; HUSSAIN, M.A. Thermal analysis and solution calorimetry studies on losartan polymorphs. Pharm. Res., v.10, n.12, p.1793-1795, 1993.

YOSHIDA, M.I.; GOMES, E.C.L.; SOARES, C.D.V.; CUNHA, A.F.; OLIVEIRA, M.A. Thermal analysis applied to Verapamil hydrochloride characterization in pharmaceutical formulations. Molecules, v.15, n.4, p.2439-2452, 2010. 
YU, L. Amorphous pharmaceutical solids: preparation, characterization and stabilization. Adv. Drug Delivery Rev., v.48, n.1, p.27-42, 2001.

YU, L.X.; FURNESS, M.S.; RAW, A.; OUTLAW, K.P.W.; NASHED, N.E.; RAMOS, E.; MILLER, S.P.F.; ADAMS, R.C..;FANG, F.; PATEL, M.R.; HOLCOMBE, O.F.; CHIU, Y-Y.; HUSSAIN, A.S. Scientific considerations of pharmaceutical solid polymorphism in abbreviated new drug applications. Pharm. Res., v.20, n.4, p.531-536, 2003.

ZENCIRCI, N.; GELBRICH, T.; KAHLENBERG, V.; GRIESSER, U.J. Crystallization of metastable polymorphs of phenobarbital by isomorphic. Cryst. Growth Des., v.9, n.8, p.3444-3456, 2009.
ZENCIRCI, N.; GELBRICH, T.; APPERLEY, D.C.; HARRIS, R.K.; KAHLENBERG, V.; GRIESSER, U.J. Structural features, phase relationships and transformation behavior of the polymorphs I-VI of phenobarbital. Cryst. Growth Des., v.10, n.1, p.302-313, 2010.

ZHENHONG, W.; YONGGANG, Y. Determination of polymorphism captopril by DSC. Chin. Pharm. J., v.25, n.12, p.1195-1196, 2011.

Received for publication on the $11^{\text {th }}$ of December 2012 Accepted for publication on the $11^{\text {th }}$ of September 2013 